\title{
KNELPUNTE IN DIE HEDENDAAGSE WESTERSE GESIN
}

\author{
PROF. DR. ANNA F. STEYN
}

\section{INLEIDING}

Die gesin as instelling is waarskynlik een van die belangrikste instellings waaraan die mens deel het, en een wat deur die eeue heen en nog steeds die aandag van die mens vanuit uiteenlopende sektore van die samelewing soos byvoorbeeld die letterkunde, die gods diens, die politiek, en gedurende die laaste halfeeu en meer, die geesteswetenskappe soos die sosiologie, die sielkunde en die maatskaplike werk, geniet het.

Een van die uitsprake oor die gesin wat 'n mens baie dikwels teenkom, is nl. dat die "gesin die ruggraat van die volk is" - n cliché wat so dikwels herhaal word dat dit heeltemal gemeenplaas en aigesaag geword het.

Tog, as op die betekenis van hierdie stelling ingegaan word, dan blyk dit duidelik dat dit deur die eeue heen nog niks van sy waarheid verloor het nie, en dat dit in moderne tye weliswaar ook nog deur die resultate van wetenskaplike navorsing ondersteun word.

Hoe waar dit nog steeds is, kom dan ook besonder goed na vore indien ons op die funksies van die gesin en veral op die twee kernfunksies van die moderne gesin let.

(i) Die Sosialiseringsfunksie

Die eerste funksie wat ek hier wil noem, is die sosialiseringsfunksie, wat met die persoonlikheidsvorming van die kind verband hou. Dit is 'n algemeen bekende feit dat wanneer die kind gebore word, hy nog 'n totaal ongevormde persoonlikheid het. Sy eerste ondervindings in die lewe doen hy direk in die gesin op, en dit is deur hierdie basiese verkeer met sy gesin in sy eerste lewensjare dat die basis van sy persoonlikheid en van die volwasse mens wat hy eendag gaan wees, gelê word.

Van die belangrikste ervaring vir sy gesonde vorming in hierdie eerste lewensjare, is die liefde wat hy in die eerste instansie van sy moeder en van die ander huislede ontvang en die dissipline wat hy op 'n effe later stadium van sy ouers begin ontvang.

Hierdie regte kombinasie van liefde en dissipline verskaf aan die kind die le:ding en die sekuriteit waardeur hy leer om nie so uiters selfgesentreerd te wees en net aan sy eie behoeftebevrediging te dink nie, maar om andere in aanmerking te neem en om met ander gesonde sosiale verhoudings aan te gaan. 
Dit is ook in hierdie atmosfeer van liefde en rigtinggewende dissipline dat die kind sy basiese waardes, sy godsdiens-, sy etiese en morele waardes en lojaliteit teenoor sy breëre gemeenskap aanlecr, en dat daar by hom die bereidwilligheid en basiese motivering vasgelê word om aan die norme en waardes van sy eie groep te konformeer. Hierdie waardes dra by tot die integrasie van sy persoonlikheid en gee in sy latere lewe aan hom rigting en standvastigheid. Daar word dus in kort van die kind 'n sosiale wese gemaak, en die ideaal in dié verband is dat hy mettertyd in ' $n$ emosioneel werklik volwasse en gebalanseerde persoonlikheid sal ontwikkel wat in staat sal wees om sy plek in die samelewing op ' $n$ volwaardige wyse vol te staan.

Vir die suksesvolle sosialisering van die kind is dit egter uiters noodsaaklik dat die gesin 'n kerngesonde eenheid moet vorm, in dié sin ciat die verhoudings tussen die man en die vrou, die man $\epsilon$ n die kinders en die vrou en kinders met ' $n$ minimum disfunksionele wrywing moet verloop. Indien hierdie verhoudings nie reg is nie, word die kind dikwels onherstelbare skade aangedoen, en kan die kind diepgaande persoonlikheidsprobleme ontwikkel, wat dit vir hom moeilik sal maak om normale maatskaplike verhoudings te handhaaf en as volwassene eendag sy plek as lid van die samelewing vol te staan.

Om maar ' $n$ enkele voorbeeld hier te noem, toon Mapler en Rabinovitch (in Eisenstein 1956) aan hoedat die ontwikkelende persoonlikheid van die kind geskaad kan word wanneer die ouers die kind as óf pion óf as bondsgenoot in 'n situasie van huwelikskonflik gebrui, waar hulle die volgende sê:

„The normal course of development is impeded if children are forced to play various unnatural roles within the intrafamilial psycho-pathology. One such role is that of pawn, sometimes from birth on. Dr. Despert cites the situation in which a child is conceived to cement a marriage which already stands in jeopardy. These children from their earliest life have been given an enormous task which their parents themselves could not achieve... Such children tend to suffer from great emotional insecurity, wavering loyalties, ambivalance and guilt feelings which may lead to ego and super-ego defects, inability to form stable object relationships, and may result in character deformities, depression or other narcisistic neuroses.

"Closely alied in its consequences to role of pawn is the role of confidant to either or both parents... who are hostile to each other. As the confidant, the child is 
burdened beyond capacity of the immature stage of his ego development. These parents rarely spare the child such traumatic and perplexing details as those pertaining to cruelties inflicted by the partner or luridly suggestive material pertaining to their sexual experience. The child is subsequently hampered in his psychosexual development, and either turns away from sex altogether or else retains immature emotional attitudes and distorted patterns instead of normal heterosexual relationships." (pp. 52-53.) Bossard en Boll (1960) sê oor die algemeen in hierdie verband: "Among the problems which such children face are basic internal conflicts... usually restraints upon behaviour and conversations; feeling of inferiority, self pity, resentment, or disappointment; continuing preoccupation with personal problems; the development of critical attitudes toward parents; and breaks in continuity of emotional and intellectual development." (p. 428.)

(ii) Stabilisering van die volwasse persoonlikheid:

Die gesin is nie net vir die opgroeiende geslag van belang nie maar het ook 'n tweede belangrike funksie, en weliswaar ten opsigte van die volwassenes in die gesin, naamlik die handhawing van die emosionele stabiliteit van die volwassenes.

Wat hierdie funksie betref, kan daarop gewys word dat in die moderne stedelike lewe wat deur 'n rasionele ekonomie gedomineer word, daar ' $n$ geweldige hoë lewenstempo gehandhaaí en baie hoë eise aan die mens gestel word, wat tot ' $n$ algemene hoë spanning by hom lei. Die werksituasie van die mens is verder van so in aard dat dit nie maklik is om binne die sfeer daarvan hierdie spanning te kan verlig en emosionele ontlading en herstel te kan verkry nie. Dit is in der waarheid feitlik nog net in die gesin waar daar sterk emosionele bande tussen die man en vrou en kinders is waar die individu nog aanvaar word vir die persoon wat hy is, waar daar nie besondere prestasies van hom vereis word nie, en waar hy dus ten volle kan ontspan en sy emosionele balans weer kan vind (Cilliers, S.P., 1960, p. 59).

Indien die gesinsverhoudings nou van so 'n aard is dat daar reeds binne die gesin spanninge is, sal die gesin nie hierdie addisionele las van die spanninge van die buitelewe kan dra nie. Dit is dus ook slegs waar die gesin basies ' $n$ kerngesonde eenheid is dat hy doeltreffend in hierdie moeilike funksie kan voorsien. 
Samevattend kan dan van hierdie belangrikheid van die gesin gesê word dat 'n gesonde gesinslewe uiters noodsaaklik vir die ontwikkeling en die instandhouding van gesonde persoonlikhede is - gesonde persoonlikhede waarsonder daar nie 'n gesonde gemeenskapslewe uitgebou kan word nie.

\section{VOORTBESTAAN VAN GESIN AS INSTELLING}

Hoewel die gesin, soos duidelik uit die voortgaande blyk, so 'n ontsettend belangrike instelling is, was die gesin in die Westerse lande vir die laaste eeu of wat - en in Suid-Afrika vir die afgelope half-eeu - aan sulke drastiese verandering onderhewig, dat daar by sommige persone twyfel ontstaan het oor die voortbestaan van die gesin as instelling, en is die vraag gestel of ons nie hier met ' $n$ totale disintegrasie van die gesinslewe te doen gaan kry nie. So byvoorbeeld het die gesin as gevolg van die proses van strukturele differensiasie 'n groot aantal van sy funksies, bv. sy produksiefunksie, sy beskermende funksie, sy godsdiensfunksie, sy politiekefunksie, ens. verloor deurdat nuwe strukture buite die gesin dit oorgeneem het, en slegs enkele funksies, waarvan die voorgenoemde twee die belangrikste is, het behoue gebly. Hierdie „verlies aan funksie" saam met die hoë en steeds toenemende egskeidingssyfer, die afname in die geboortesyfer, en die veranderende seksmoraliteit, is deur sommige - ook hier in Suid-Afrika - as aanduidend van die totale disintegrasie van die gesin as instelling interpreteer. (Sien Parsons en Bales, 1955, p. 3.)

In Suid-Afrika het daar stemme opgegaan wat hierdie pessimisme ten opsigte van die gesinslewe hier ter lande gedeel het en as doemprofete die verval van die gesin as instelling voorspel het. So byvoorbeeld het wyle prof. Keyter (1940, p. 131-146) hom hieroor uitgelaat, en hy $\mathrm{kom}$ in hierdie verband tot die volgende vraagstelling: ,Is dit 'n wonder dat ook die Afrikaanse huis besig is om leeg te loop en die Afrikaanse gesin met volslae bankrotskap aan alle gesinswaardes bedreig word?", en 'n endjie verder aan sê hy: „Die eenmaal so geroemde selfstandigheid en praktiese oorspronklikheid van die Afrikaanse gesin is so goed as vernietig of vinnig aan die uitsterwe..." (p. 144) en "Verdere kommentaar is oorbodig. Uit die voorgaande feite en syfers blyk duidelik genoeg dat ook Suid-Afrika en die Afrikaner dieselfde weg opgaan as die ander beskaafde lande en besig is om die gesin, die onvervangbare grondslag van individuele en nasionale welvaart, te ondermyn en te vernietig"' (p. 144).

Dat hierdie pessimistiese uitgangspunt nie bewaarheid is nie, en dat dit ook nie goeie grond het nie, kom gelukkig deur bepaalde navorsingsresultate baie duidelik aan die lig. 
So byvoorbeeld kan aangetoon word dat die mens nog nie sy basiese geloof in die huwelik verloor het nie, want ten spyte van die hoë egskeidingsyfer leef ' $n$ steeds groter wordende persentasie van die bevolking in die huwelikstaat. So kan aangetoon word dat die persentasie van die bevolking wat getroud is vanaf $34,4 \%$ in 1911 vermeerder het na $45,4 \%$ in 1970 , terwyl die persentasie geskeides in die bevolking slegs vanaf $0,1 \%$ in 1911 na $1,6 \%$ in 1970 vermeerder het. (Sien Tabel I.)

TABEL 1: HUWELIKSTAAT VAN BLANKE BEVOLKING VAN DIE REPUBLIEK VAN SUID-AFRIKA - 1911-1970

\begin{tabular}{|c|c|c|c|c|c|c|}
\hline \multirow[b]{2}{*}{ Huwelikstaat } & \multicolumn{6}{|c|}{ Jare } \\
\hline & 1911 & 1921 & 1936 & 1951 & 1960 & 1970 \\
\hline Nooit getroud & 62,5 & 59,9 & 55,5 & 49,6 & 49,5 & 48 \\
\hline Getroud $\ldots . . . . . . . . . . . . .$. & 34.4 & 36,1 & 39,7 & 44,6 & 44,6 & 45, \\
\hline Wedustaat & 3,0 & 3,7 & 4,1 & 4,7 & 4,5 & 4, \\
\hline Geskei $\quad \ldots \ldots \ldots \ldots . . . . . . .$. & 0,1 & 0,3 & 0,5 & 1,1 & 1,3 & 1 \\
\hline Ander $\quad \ldots \ldots . . . . . . . . . . .$. & 0,02 & 0,03 & 0,1 & 0,02 & 0,1 & 0 \\
\hline TOTAAL $\%$ & 100,02 & 100,03 & 100 & 100 & 100 & 100 \\
\hline
\end{tabular}

Gekry uit:

Uniestatistiek oor vyftig jaar 1910-1960 en

Bevolkingsensus 6 Mei 1970 Verslag No. 02-01-07

Die toename in die getal persone wat in die wedustaat leef, kan waarskynlik verklaar word in terme van die ouer-wordende bevolking. Hierdie ouerwordende bevolking is egter nie ' $n$ verklaring vir die toename in die persentasie persone wat in die huwelikstaat leef nie, soos duidelik blyk as die vorige gegewens met die gegewens in die volgende tabel vergelyk word:

TABEL 2: PERSENTASIE VERDELING VAN DIE BEVOLKING VAN DIE REPUBLIEK VAN SUID-AFRIKA VOLGENS OUDERDOM, 1911-1970

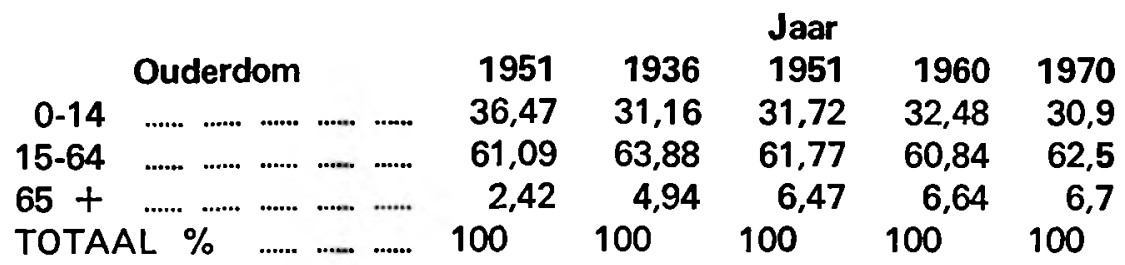

Gegewens uit Piek, B. J.: Demografiese studie van tendense in die leeftydsamestelling van ' $n$ bevolking, met besondere verwysing na blankes in Suid-Afrika en Suid-Afrikaanse Statistiek 1972 en

Suid-Afrikaanse Statistieke 1972 
Afgesien van die feit dat ' $n$ toenemende $\%$ van die bevolking in die huwelikstaat leef, kan verder daarop gewys word dat ' $n$ baie hoë $\%$ van die egskeidingsyfer, $\mathrm{nl} \pm 35 \%$, plaasvind tussen persone wat geen kinders het nie, en dat in hierdie gevalle nie werklik van gesinsopbreking gepraat kan word nie.

Interessant genoeg het hierdie persentasie oor die laaste vyftien jaar baie konstant op ongeveer $35 \%$ gebly, soos uit die volgende tabel gesien kan word.

TABEL 3: PERSENTASIE EgSKEIDINGS VOLGENS KINDERTAL IN DIE REPUBLIEK VAN SUID-AFRIKA - 1956-1971*

\begin{tabular}{|c|c|c|c|c|c|}
\hline \multirow{3}{*}{$\begin{array}{l}\text { Aantal } \\
\text { Geen }\end{array}$} & \multirow[b]{2}{*}{ Kinders } & \multicolumn{3}{|c|}{ Jare } & \multirow{2}{*}{ Totaal } \\
\hline & & $1956-1960$ & 1961-1966 & $1967-1971$ & \\
\hline & ................... & 38,8 & 35.7 & 35,1 & 35,5 \\
\hline & .......................... & 23,8 & 23,3 & 23,2 & 23,4 \\
\hline ....... & $\ldots . . . . . . . . . . .$. & 22,0 & 21,2 & 21,2 & 21,5 \\
\hline ........ & ........................ & 10,0 & 11,1 & 11,6 & 11,1 \\
\hline $4+\ldots \ldots$ & ......................... & 8,3 & 8,8 & 8,7 & 8,5 \\
\hline ATL & ........ & 100 & 100 & 100 & 100 \\
\hline
\end{tabular}

Gegewens verwerk uit:

* Versłag oor egskeidings in Suid-Afrika 1967-1969 - No. 07-04-03.

Verslag oor egskeidings in Suid-Afrika 1970-No. 07-04-04.

Verslag oor egskeidings in Suid-Afrika 1971 — No. 07-04-05.

Statistiese Jaarboek 1966.

'n Verdere belangrike aspek wat dui op die feit dat die gesin as instelling nog lank nie vernietig is nie, is die aard van die woningspatrone. Basies is die gesin ' $n$ residensiële eenheid en indien die gesin as instelling aan die taan was, sou 'n mens kon verwag dat die belangrikheid van die gesinswoning as die plek wat deur mense verkies word, drasties sou verminder.

Tog, as statistiek in hierdie verband nagegaan word, kom dit sterk na vore hoe belangrik die huis nog as basiese vorm van verblyf beskou word. (Ongelukkig is die nuutste sensus-materiaal nog nie beskikbaar nie.)

TABEL 4: WONINGSVORM IN REPUBLIEK VAN SUID-AFRIKA 1960*

\section{Tipe Huis}

Huis

Woonstel ..........-

Hotel en losieshuis .....

Inrigting (.....................

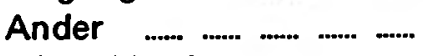

TOTAAL $\%$

\section{Nooit \\ Getroud}

80,9

$$
6,7
$$

2,0

1,0

9,4

100
Ander

Getroud Geskeid en Totaal

Wedustaat

85,8
11,4
1,6
0,2
1,0
100

69,2

17,3

5,6

3,1

4,8

100
82,4

9,4

2,0

0,8

5,4

* Uit Bevolkingsensus 6 September 1960. Boekdeel 7 No. 2. 
In die lig van bogenoemde gegewens word die disorganisasie wat wel in die gesinslewe voorkom, soos bv. die toename in en hoë egskeidingsyfer, die toenemende permissiwiteit, ens. geinterpreteer as simptome van die geweldige veranderinge waaraan die gesin onderhewig is en as gevolg waarvan daar stremminge ontwikkel het wat die huweliksverhouding onstabiel maak en makliker laat opbreek. Die interpretasie dat die mate van disorganisasie in die gesin getuig van ' $n$ totale verbrokkeling van die gesin as instelling, word dan vandag in die sosiologie nie meer aanvaar nie.

Afgesien van positiewe tendense hierbo beskryf, het daar in enkele lande, waar die belangrikheid van die gesin onderskat en negeer is, en waar pogings aangewend is om dit uit die samelewingskonteks uitgeskakel te kry, ontwikkelings plaasgevind wat dui op die onvernietigbaarheid van die gesin.

So wys Timasheff* bv. daarop dat in 1920 in die nuutonstaande kommunistiese staat in Rusland 'n program ontwikkel is waarvan die doel was om die gesinslewe soos dit in die Westerse beskawing bestaan, uit te wis, $\mathrm{cn}$ was dit die basiese uitgangspunt dat die gesin nie langer vir die individu of die staat nodig was nie. ' $n$ Hele verskeidenheid van maatreëls is geneem om hierdie doel te bereik, en die staat het ook weliswaar daarin geslaag om die gesinsbande grotendeels te verswak. Met hierdie verswakking van die gesinsbande het egter ' $n$ aantal sosiaal-patologiese verskynsels soos ' $n$ geweldige daling in geboortesyier, jeugmisdaad, verswakking van gemeenskapsbande en ' $n$ algemene toestand van wanorde hul kop uitgesteek. Om hierdie negatiewe aspekte uit te skakel, het die Russiese regering geen ander keuse gehad as om stappe te neem om die gesin weer in ere te herstel en op te bou nie.

Dieselfde verskynsel het hom op die Kibbutz afgespeel, hoewel miskien nie in so 'n drastiese vorm nie. Wat wel daar gebeur het, is dat die gemeenskapslewe as die oorwegend belangrike aspek in die organisasie van die Kibbutz beskou is, en is die verdeling van arbeid en inkomste, asook die opvoeding van die kinders so ingerig, dat die gesinslewe as sodanig geen plek in die Kibbutz gehad het nie. Ten spyte daarvan kom Spiro (in Bell en Vogel, 1960, pp. 64-75) in 'n stuk navorsing van hom tot die slotsom dat hoewel die gesin aanvanklik afwesig skyn te gewees het, dit tog weer eens uitgekristalliseer het, en dat die gesin as 'n eiesoortige unieke groep, met 'n baie gespesialiseerde funksie, te wete die koesterende en emosioneel voedende funksie, baie beslis op die Kibbutz bestaan. Die gesinslewe het dus ten spyte van die feit dat dit doelbewus uitgesny is, op ' $n$ heeltemal spontane wyse weer eens gevestig geraak, en is die belangrikheid daarvan ook hier erken.

* (in Bell en Vogel, 1960, pp. 55-63.) 
Nog ' $n$ voorbeeld wat in hierdie verband genoem kan word, is die geval van Swede. Hoewel alombekend as die land waar daar die grootste mate van permissiwiteit t.o.v. voorhuwelikse geslagsverkeer bestaan, wys Linner (1960, Hoofstuk 3) daarop dat hierdie permissiwiteit nie met promiskuiteit bestaan nie. So wys sy daarop dat waar voorhuwelikse omgang plaasvind, dit hoofsaaklik tussen persone is tussen wie daar ' $n$ sterk affektiewe band of reeds 'n verlowing is. Waar persone dan in die huwelik tree, word buitehuwelikse omgang net so sterk op gefrons as in enige die Westerse lande. Daarby leef de meerderheid van die volwasse bevolking, $\mathrm{nl} .61 \%$, in die huwelikstaat - ' $n$ persentasie wat nie veel kleiner as dié van Amerika, $\mathrm{nl} .67 \%$, is nie. Die huwelikstaat is dus daar ook nog die basiese lewensvorm waaraan voorkeur gegee word.

Hierdie voorgaande gegewens dui baie duidelik daarop dat die gesin as instelling feitlik onvernietigbaar is.

Hoewel dit dus uit de voorgaande gegewens baie duidelik blyk dat ons eintlik ba:e optimisties oor die voortbestaan van die gesin as sodanig kan wees, kan ons tog nie ons oë sluit vir die feit dat daar jaarliks ' $n$ toenemende getal individuele huwelike is wat in die egskeidingshof land nie, en dat daar in hierdie proses talle kinders by betrokke is, wie se persoonlikheidsontwikkeling daardeur geskaad kan word. Ook kan ons nie ons oë sluit vir die feit dat daar proporsioneel ' $n$ toename is in die aantal huwelike wat wel in die egskeidingshof ein dig nie.

Hierdie relatiewe toename in egskeidings in Suid-Afrika kom baie duidelik na vore as ons die egskeidingssyfer vir ' $n$ aantal jare nagaan, nl. vanaf 1,9 per 1000 huwelike in 1918, 6,4 in 1960 en 9,5 in 1971 , soos duidelik uit die volgende tabel blyk.

TABEL 5: EGSKEIDINGSYFER, REPUBLIEK VAN SUID-AFRIKA, 1918-1971*

$\begin{array}{cccc}\text { Jaar } & \text { Egskeidingsyfer } & & \\ 1918 & 1,9 & 1963 & 6,6 \\ 1938 & 4,2 & 1964 & 7,0 \\ 1940 & 3,9 & 1965 & 7,0 \\ 1945 & 7,8 & 1966 & 7,4 \\ 1950 & 6,3 & 1967 & 7,3 \\ 1955 & 5,9 & 1968 & 7,7 \\ 1960 & 6,4 & 1969 & 8,7 \\ 1961 & 6,5 & 1970 & 9,1 \\ 1962 & 6,6 & 1971 & 9,5\end{array}$

* Egskeidings, Suid-Afrika, 1971. Verslag No. 07-04-05. 
Hoe groot die omvang van egskeiding werklik is, kom baie duidelik na vore as ons na die rou syfers gaan kyk. So byvoorbeeld is vanaf 1938 tot 1971 altesaam 145476 egpare se huwelike ontbind waarby 191426 kinders betrokke was. In die 10 jaar van 1962-1971 is altesaam 61194 huwelike geskei waarby 86200 kinders betrokke was. (Statistiese Jaarboek 1966, en Verslae oor egskeiding in SuidAfrika No. 07-04-03 en 07-04-04 en 07-04-05). Hierdie syfers sluit nie eers die aantal mense, volwassenes en kinders in, wat betrokke is in gesinne waar swak verhoudings bestaan nie, en waarvan dit 'n onbegonne taak is om die getalle te bepaal. As dit ook nog in aanmerking geneem moet word, sal die getal kinders wie se ontwikkeling op een of ander wyse benadeel word, nog veel hoër wees.

Hoewel daar skynbaar dus nie rede om te pessimisties te wees oor die verval van die gesin as instelling in totaliteit nie, is daar wel rede om bekommerd te wees oor die aantal individuele huwelike en gesinne waar daar swak verhoudings is wat in 'n groot aantal gevalle op egskeidings uitloop, en waardeur veral die kinders wat die toekomstige volwassenes is, se persoonlikheidsontwikkeling ernstig gestrem word.

Dit is dringend noojsaaklik dat grondige ondersoek ingestel moet word na die knelpunte in die gesinslewe wat deur die veranderings in die huidige samelewingsopset na vore kom en die gesinstabiliteit bedreig. Slegs as ons kennis van hierdie knelpunte dra, sal ons kan begin om dit te verminder of uit te skakel.

\section{KNELPUNTE IN DIE HUIDIGE WESTERSE GESIN}

Wanneer daar 'n studie van die knelpunte in die huidige Westerse gesin gemaak word, sal dit vanuit twee vertrekpunte gedoen kan word.

In die eerste instansie kan gekonsentreer word op die persoonlikheidsgebreke en -probleme van die twee egliede, en sal aangetoon kan word hoe hierdie persoonlikheidsgebreke, soos bv. emosionele onvolwassenheid, daartoe lei dat die huweliksverhouding kan opbreek. Eisenstein in sy werk ,Neurotic Interaction in Marriage het byvoorbeeld sy ontleding van huweliksproblematiek oor hierdie boeg gegooi.

In die tweede instansie kan daar 'n ontleding van die knelpunte gemaak word soos dit voortspruit uit die besondere aard van die samelewing, die besondere aard van die gesin en die wyse waarop die gesin binne hierdie samelewing funksioneer. Die benadering wat hier gebruik gaan word is $\mathrm{nl}$. die tweede wat uit en uit sosiologies van aard is.

Aangesien die knelpunte, soos reeds gestel, die uitvloeisel van drastiese veranderings in die samelewing is, sal ons, as ons 'n studie van hierdie knelpunte wil maak, in die eerste instansie na die aard en funksionering van die meer tradisionele en stabiele samelewings- 
en gesinstrukture moet kyk, dan na die faktore wat die veranderinge laat plaasvind het, en dan eers na die veranderde samelewings- en gesinstrukture self en die knelpunte wat daaruit vir die gesinslewe voortspruit. Slegs as hierdie knelpunte gesien word teen die agtergrond van die meer stabiele en tradisionele gesin, is dit moontlik om werklik in diepte insig te kry in die ontwikkeling en aard van die knelpunte.

Om mee te begin, wil ek dus baie kortliks na die struktuur en dinamika van die stabiele tradisionele gesin kyk.

\section{1) Die tradisionele pre-Industriële gesin}

Aangesien samelewings- en gesinstrukture voortdurend aan die verander is, is dit belangrik om te bepaal watter era in die geskiedenis geneem moet word om as tiperend van die tradisionele gesin te dien. Navorsing het in hierdie verband aangetoon dat die mees geskikte era waarmee die moderne westerse gesin vergelyk kan word dié van die eeu of wat van voor die Industriële Revolusie is. Die Industriële revolusie was nie net 'n tegnologiese revolusie nie, maar was ook 'n indringende maatskaplike revolusie waardeur die totale samelewingstruktuur sowel as die struktuur en verhoudingspatrone binne die gesin indringende veranderings ondergaan het.

'n Besondere kenmerk van die pre-industriële samelewing in Wes-Europa en Engeland is die feit dat die grootste persentasie van die bevolking $( \pm 90 \%)$ in 'n wêreld van kleindorpies, markgenootskappe en landbouhoewes gewoon het, wat deur 'n selfonderhoudend landbou-ekonomie gekenmerk is. (Neidhardt, 1966, p. 23-25.)

Die samelewingstruktuur in die pre-industriële Era was besonder eenvoudig en ongedifferensieerd van aard en ons het hier basies met ' $n$ eenvoudige afstammingsamelewing te doen gehad, waarin verwantskapsbande ' $n$ belangrike rol gespeel het. Een van die belangrikste elemente binne hierdie samelewingstruktuur was dan ook die Grootfamilie of die sg. uitgebreide gesin, wat 'n basiese maatskaplike en ekonomiese selfversorgende eenheid gevorm het. Selfs in die pre-industriële stede waar die gildestelsel gebloei het, word gevind dat hierdie gildestelsel in essensie basies op die lyne van die Grootfamilie en quasiverwantskapsbande uitgebou is.

Ook kry ons dat die samelewingstruktuur hier in Suid-Afrika voor die ontdekking van goud en diamante, en die gevolglike vinnige ontstaan van en geweldige toeloop na stede en industrialisering ' ooreenkoms met die samelewingstruktuur in Wes-Europa van voor die industriële Revolusie toon, en dat die uitgebreide gesin of die sg. Grootfamilie ' $n$ geweldige belangrike en sentrale rol in die maatskaplike organisasie van die Suid-Afrikaanse samelewing wat grotendeels landelik van aard was, gespeel het. 
Daar word ook deur sommige outeurs na die plattelandse gesin in Suid-Afrika as die sg. patriargale familie verwys, en hulle toon aan dat die lewe van die mens eintlik binne hierdie verwantskaps- en gesinsbande en ook binne die lande van sy kerk en gemeenskap verloop het. (Sien Keyter, p. 89 en Cronje en Venter, 1958, pp. 141.)

In ' $n$ ontleding van die struktuur van hierdie gesinstipe moet daarop gewys word dat 'n groot aantal gesinne deur die lyn van afstamming aan mekaar gesnoer was, om so die uitgebreide gesin te vorm. Dit kom daarop neer dat die seuns met hulle vrouens en kinders by die ouers inwoon en dat verskillende generasies saam een huishouding uitmaak, en dat die groep verwante eintlik in ' $n$ hegte primêre gemeenskapsverband met hul lewens eng verweef, geleef het.

Een besondere kenmerk van hierdie groot familie is die plek wat die kerngesin - dit wil sê die man, vrou en hulle eie kinders hierbinne inneem. Die kerngesin vorm naamlik nie 'n eie afsonderlike selfstandige eenheid nie, maar dit is stewig in die meer omvattende grootfamilie ingekapsel. Die lede van die kerngesin het dus nie selfbeslissing oor hulle eie lot nie, maar hulle vorm deel van 'n groter groep, aan wie hulle lotsgebonde was.

Die basiese outoriteit in hierdie groot familie is deur die manlike hoof uitgeoefen en is na sy dood op sy oudste seun oorgedra. Die vrou het geen of weinig outoriteit gehad nie - inderwaarheid is sy dwarsdeur haar lewe as minderjarig beskou - en sy is deur haar lewe eers aan die outoriteit van haar vader en daarna die outoriteit van haar man onderwerp.

Wat die dinamika van hierdie groot-familie betref, word daar oor die algemeen gevind dat die wyse waarop dit funksioneer tot 'n baie groot mate van sekuriteit by die individu op verskillende vlakke bydra.

In die eerste instansie het die lede van die groot familie in 'n groot mate ekonomiese sekuriteit. Die groot familie het 'n bestaansekonomie, en die hele groep werk saam vir die verkryging van lewensonderhoud. As daar ekonomiese probleme by sommige lede van die groot-familie ontstaan en die betrokke persone nie meer self in die lewensonderhoud kan voorsien nie, dan is dit voor die hand liggend dat die ander lede van die uitgebreide gesin 'n bydrae in dié verband sal doen. So word die kind sonder ouers, die gebreklikes. siekes en ook die bejaarde persone binne die groter gesinsverband versorg en het die probleem van nooddruftigheid nie maklik ontwikkel nie. Hoewel te veel persone wat nie vir hulself kan voorsien nie binne so ' $n$ gesin ' $n$ te groot ekonomiese belasting en dus nadelig kan wees, word tog oor die algemeen gevind dat hierdie toedrag van sake tot 'n baie hoë mate van ekonomiese sekuriteit by die lede bydra. 
Tweedens kan daarop gewys word dat die besondere aard en samestelling van die grootfamilie tot 'n baie hoë mate van emosionele sekuriteit lei. So is ' $n$ besondere kenmerk van die grootfamilie die feit dat die huishouding altyd uit 'n groot aantal persone bestaan, en dat die lewenspatroon van die individu so ingerig is dat hy sy tyd en aandag tussen 'n groot aantal persone moet versprei. Gevolglik is die emosionele bande tussen die lede van die gesin meer ekstensief as intensief van aard, en daar is nie 'n groot verskil in die aard van die emosionele bande tussen die lede van die gesin en persone buite die gesin nie. Belangrik hier is egter dat hoewel die persoon se emosionele lewe nie juis intensief is nie, hy tog voortdurend in kontak met en omring van mense is en die probleem van eensaamheid nie een is wat in die uitgebreide gesin voorkom nie.

' $n$ Verdere belangrike kenmerk van die verhoudingspatroon in hierdie gesins-tipe is dat in hierdie groot huishouding waar baie kategorieë van verwante saamwoon, gevind word dat die verhoudings tussen die verskillende kategorieë van verwante in 'n baie groot mate voorskriftelik en formeel van aard is. Daar bestaan 'n bepaalde formaliteit tussen die man en die vrou en ook tussen die ouers en die kinders en groot klem word op die korrektheid van optrede in hierdie verband gelê.

Dit lei daartoe dat hoewel 'n persoon tussen 'n groot aantal ander persone leef, hy presies weet hoe om teenoor alle kategorieë van verwante o? te tree, en dat daar feitlik geen onsekerheid by hom in hierdie verband kan ontwikkel nie. Hierdie toedrag van sake lei daartoe dat die persone wat in die grootfamilie opgroei 'n besondere sterk mate van emosionele sekuriteit ontwikkel.

Die feit dat die persone in die uitgebreide gesin so voortdurend van ander mense omring is met wie mense in bepaalde goedgedefineerde verhoudings staan, het verdere belangrike implikasies vir die individue binne die groter gesinsverband:

(i) So byvoorbeeld is hierdie persone wat in so ' $n$ uitgebreide huishouding woon baie sigbaar vir mekaar en (Goode, 1966, p. 54) sien hulle mekaar mecr dikwels as wanneer elk van die kerngesinne sy eie afsonderlike woning sou hê. Saam hiermee gaan die feit dat daar ' $n$ totale

(ii) gebrek aan privaatheid is en dat die gedrag van die gesinslede teenoor mekaar nie hulle eie saak is nie, maar dat ander lede van die groter huishouding oor die huweliksverhouding en ouer-kind verhouding toesig kan hou, en inspraak op die interne aangeleenthede van die kerngesin het.

Hierdie verhoogde sigbaarheid en gebrek aan privaatheid dra nou ook in 'n hoë mate by tot die uitoefening van 'n groot mate van 
(iii) maatskaplike beheer. Bossard en Boll (1960, p. 61) sê in dié verband: .With large-family living go emphasis on qualities of behaviour which are group essentials. Conforming is valued above self-expression ... and, as a rule, the greater number of persons there is the more numerous and stringent the rules." Die lede van die huishouding het dan ook die verpligting om op mekaar se gedrag te let om te verseker dat die korrekte optrede uitgevoer word. Gewoonlik het die lede van die huishouding groot belang daarin dat die huweliksverhouding en gesinsverhoudinge gehandhaaf word, en daar word in geval van gesins en verhoudingsprobleme, beheer en druk op die kerngesin uitgeoefen wat tot die stabiliteit van die gesin bydra. Afgesien van die beheer kry die lede van die kerngesin waar daar huweliks- en gesinsprobleme ontwikkel ook sterk emosionele steun van die ander lede van die uitgebreide gesin, deurdat hulle weens die gebrek aan privaatheid met groot vrymoedigheid hul probleme met veral die ouer lede kan bespreek en daardeur in 'n

(iv) struktureel sterk ondersteunde posisie geplaas word, wat verder tot gesinstabiliteit bydra.

Die uitgebreide gesinsisteem met die groot getalle persone in die huishouding het ook belangrike implikasies vir die opvoeding en sosialisering van die kind. So byvoorbeeld is dit nie net die eie ouers wat dissipline op die kind uitoefen nie, maar kan ' $n$ verskeidenheid van volwasse persone die kind dissiplineer. Die probleem wat dissiplinering t.o.v. kinders in die moderne kerngesin veroorsaak, $\mathrm{nl}$. die ontwikkeling van diepgesetelde konflikterende emosies by die kinders (Borsard en Boll 1960, p. 55) soos in die volgende afdeling aangedui sal word, is nie by die kind in die uitgebreide gesin aanwesig nie.

Bossar en Boll (1960, p. 59) wys ook daarop dat die lewe in die groot gesinsisteem tot ' $n$ vroeë aanvaarding van lewenswerklikhede lei. Die kinders word op ' $n$ vroeër stadium aan hulself oorgelaat en leer ook om lewensprobleme op ' $n$ vroeër stadium in 'n groter mate te hanteer. Hulle sê in dié verband: „,The large-family members learn therefore to take minor disturbances in stride... it is almost as if one developed an immunity against them ..." en op 'n effens later stadium "To grow up in a large family is to come to terms with life. This seems the best way to designate the almost inevitable socializing process of large family living" (p. 63.)

Die ekstensiewe emosionaliteit van die uitgebreide gesin het verder ook besliste voordele vir kinder-ontwikkeling gehad, want weens die aanwesigheid van groot getalle persone en kinders kon die ouers onder die druk van omstandighede nie 'n oorbesitlikheid, 
'n oorbeskermende houding of besorgde angstigheid t.o.v. die kind maklik laat ontwikkel nie. Bossard en Boll sê in dié verband: "Other things being equal, the large-family system makes for a certain balance and sanity in child rearing. Our material tends to show that having many children makes for an extended accumulation of parental experience, which in turn results in a certain detached and objective attitude toward child problems" (p. 64).

'n Laaste aspek van die uitgebreide gesin wat 'n groot rol in die ontwikkeling van die kenmerkende sekuriteit van hierdie gesinstipe speel, is naamlik die aard van die rolverdeling. Die rol-differensiasie binne hierdie gesin is baie spesifiek en duidelik afgebaken, en die vrou het, afgesien van die versorging van die kinders, net soos die man, tradisioneel duidelik afgebakende ekonomiese aktiwiteite. Hierdie duidelike roldifferensiasie lei daartoe dat daar geen onsekerheid of konflik oor die rol wat elk te vervul het, is nie.

Samevattend kan dus van die aard van die uitgebreide gesin in die pre-industriële era gesê word, dat een van sy uitstaande kenmerke dié van die hoë mate van sekuriteit - ekonomiese, emosionele en rol-sekuriteit - was en dat die kerngesin as sodanig in 'n struktureel sterk ondersteunde posisie was, wat tot 'n baie hoë mate van gesinstabiliteit gelei het

2) Die Industriële Revolusie en daarmeegepaardgaande faktore wat bygedra het tot ' $n$ veranderde samelewings en gesinstruktuur

Die Industriële Revolusie in die Westerse Wêreld, saam met die eise wat deur industriële arbeid en verstedeliking gestel word, het egter daartoe bygedra dat die samelewingstruktuur, en daarmee saam die stabiele gesinstruktuur baie ingrypend verander het.

Ter toeligting moet hier daarop gewys word dat hoewel ons in hierdie konteks slegs na die proses van verandering a.g.v. industrialisering en verstedeliking in die westerse wêreld verwys, hierdie proses nie slegs tot die westerse wêreld beperk is nie. Goode (1963) wys bv. daarop dat die samclcwingstruktuur en die gesin in alle lande waar industrialisering en verstedeliking plaasgevind het, aan kenmerkende veranderinge onderhewig was.

In so verre as wat Suid-Afrika dus aan die proses van industrialisering en verstedeliking onderhewig was, sal die veranderinge dus ook hier te voorskyn tree. En dat Suid-Afrika reeds 'n geruime tyd en tans in toenemende mate aan hierdie prosesse onderhewig is, is bekende historiese feit en spreek ook duidelik uit bepaalde statistiese gegewens. Die proses van industrialisering en verstedeliking begin hier reeds gedurende die laaste helfte van die vorige eeu met die ontdekking van goud en diamante waardeur ook 'n trek na die stede begin. Industrialisering as sodanig het egter sy sterkste 
impetus gedurende Wêreldoorlog II en daarná gekry, en dit kan met reg beweer word dat ons in die rigting van 'n gedifferensieerde industriële ekonomie beweeg, waarby die verstedelikte Bantoe in ' $n$ toenemende mate inskakel. Hierdie tendens is baie duidelik as ons net na die toename van verstedeliking onder die blankes in die volgende tabel kyk.

\section{TABEL 6: GEOGRAFIESE VERSPREIDING VAN DIE BLANKE BEVOLKING VAN DIE REPUBLIEK VAN SUID-AFRIKA $-1911-1970^{*}$}

\begin{tabular}{|c|c|c|c|c|}
\hline & Jaar & Platteland \% & Stad \% & Totaal \\
\hline 1911 & 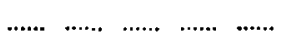 & 48,4 & 51,6 & $100 \%$ \\
\hline 1921 & 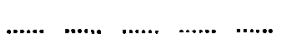 & 40,4 & 59,6 & $100^{\circ}$ \\
\hline 1936 & 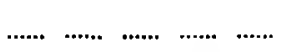 & 34,8 & 65,2 & $100^{\circ}$ \\
\hline 1951 & 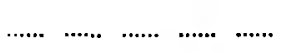 & 21,6 & 78,4 & 100 \\
\hline 1960 & 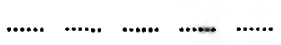 & 17,0 & 83,0 & 100 \\
\hline 1970 & …................................ & 13,3 & 86,7 & $100^{\circ}$ \\
\hline
\end{tabular}

Waar ons dus vervolgens na die veranderinge wat deur die Industriële Revolusie en verstedeliking teweeg gebring word, gaan $k y k$, is dit voor die hand liggend dat dit ook op Suid-Afrika van toepassing sal wees.

Die belangrikste verandering wat deur die Industriële Revolusie teweeg gebring is, is die feit dat die fabriek die primêre produksieeenheid in die samelewing geword het, waardeur die individu buite gesinsverband begin werk het, en die gesinslewe so van ekonomiese aktiwiteite losgemaak is. Deur die ontwikkeling van hierdie gedifferensieerde arbeids- en ekonomiese funksie, soos beliggaam in ons hedendaagse ekonomiese en beroepstelsel, is 'n proses van strukturele differensiasie aan die gang gesit, wat die struktuur van die samelewing in totaliteit verander het, deurdat meer en meer van die lewensaktiwiteite uit die gesin uitgedifferensieer het, en gespesialiseerde strukture buite die gesin ontwikkel het waarbinne hierdie lewensaktiwiteite op 'n gespesialiseerde manier in voorsien is.

Hierdie proses van strukturele differensiasie behels dus dat al meer funksies in die samelewing wat eers deur die uitgebreide gesin en verwantskapsisteem uitgevoer is, nou deur die ekonomiese- en beroepstruktuur en ook ander strukture buite die gesin geabsorbeer word en dat dit ten koste van die relatiewe belangrikheid van die uitgebreide gesin en verwantskapsisteem as strukturele komponent van die samelewing geskied het. (Cilliers, 1960, p. 9.) Cilliers (1960, p. 9) wys daarop, dat vanuit die oogpunt van die betrokke individue

* Gegewens uit:

Suid-Afrikaanse Statistieke 1972

Statistiese Jaarboek 1964 
gesien, hierdie proses behels dat baie van hulle behoeftes waarvoor vrJečr binne die raamwerk van die verwantskapstelsel voorsiening gemaak is, tans buite herdie struktuur bevredig word.

Hierdie proses behels egter nie dat die gesin nou uit die samelewing uitgeskakel gaan word nie, maar dat die gesin self 'n meer gespesialiseerde struktuur met gespesialiseerde funksies geword het, waarvan twee van die belangrikstes hiervan reeds in die inleidende paragraaf genoem is.

Afgesien van die feit dat hierdie proses van strukturele differensiasie tot die verandering in gesinsfunksies gelei het, het dit ook tot verdere indringende veranderings t.o.v. die gesinstruktuur en verhoud ngs binne die gesin gelei.

So kan daarop gewys word dat die uitgebreide gesin nie as eenheid binne die industriële opset geakkomodeer kon word nie, maar dat dit die individu geword het wat as basiese arbeidseenheid optree, 'n feit waardeur hy potensiële ekonomiese onafhanklikheid van die uitgebreide gesin en spesifiek die vaderlike huis gekry het, (Cilliers, 1960, p.8) en waardeur hy so vir sy eie lewensonderhoud verantwoordelik begin word het.

Hierdie losmaking is verder bevorder deur die feit dat die persoon soms na 'n ander geografiese area moes wegtrek na gebiede - en merendeels hier die grootstad-waar industrieë opgerig is om daar werk te kry, waardeur hul geografies van hul uitgebreide gesinsgroep verwyder geraak het, en waardeur hierdie uitgebreide gesinsgroep ook geleidelik as 'n funksionerende eenheid begin opbreek het.

'n Verdere faktor wat bygedra het tot die opbreking van die uitgebreide gesinsgroep, is dat deur die rasionele aard van die ekonomiese bedrywighede die eise gestel word dat persone nie op 'n toegeskrewe basis van ouderdom en geslag ekonomiese aktiwiteite uitvoer nie, maar dat hulle werkplasing deur hul basiese vermoëns, vaardigheid en opleiding bepaal word. Daardeur is daar heelwat t.o.v. die gesags- en status struktuur van die uitgebreide gesin ingeboet, en het differensiële maatskaplike mobiliteit binne in die uitgebreide gesin ontstaan wat die eenheid van die uitgebreide gesin nog verder benadeel het.

Hierdie proses van strukturele differensiasie asook die eise vir die beoefening van 'n beroep as gevolg van die industriële revolusie het dan mettertyd daartoe gelei dat die struktuur van die gesin geleidelik gewysig is, en dat ons tans in die westerse wêreld en ook in Suid-Afrika vir die blankes sowel as vir die verstedelikte nieblankes voor veranderde en veranderende gesinstrukture te staan kom waaraan baie knelpunte verbonde is.

In die volgende afdeling wil ek dus kortliks ingaan op die basiese verandering in die struktuur van die Westerse asook Suid- 
Afrikaanse gesin, asook die implikasies wat hierdie strukturele verandering vir die gesinsdinamika inhou, en die aard van die knelpunte wat uit hierdie situasie voortspruit.

3) Veranderings in die gesinstruktuur, en knelpunte as gevolg daarvan

Die belangrikste strukturele verandering wat die gesin sedert die aanvang van die industriële era ondergaan het, is die feit dat die kerngesin struktureel verwyderd en geisoleerd geraak het van die wyer verwantskapsisteem waarin dit ingebed en ingekapsel was, en dat hierdie kerngesin, naamlik die man en vrou en hulle afhanklike kinders, as 'n onafhanklike en afsonderlike eenheid begin funksioneer het. Dat hierdie proses van strukturele isolasie van die kerngesin ook in Suid-Afrika begin ontwikkel en vêr gevorder het, blyk duidelik uit werk deur Keyter (1940), Venter en Cronje (1958), Van der Merwe (1963) en Van der Merwe (1969). Keyter sê byvoorbeeld reeds in 1940 in hierdie verband: „In die eerste plaas het die grootte van die gesin drasties afgeneem. Die ou landelike grootfamilie, waarin dikwels drie, selfs meer geslagte saam gewoon het, het steeds kleiner en kleiner gekrimp. Vandag vind ons reeds onder ons jonggetroudes die vaste oortuiging dat dit hoogs onwenslik vir die huweliksgeluk is dat hul ouers by hulle moet inwoon. Selfs nog beter sou dit wees om na 'n ander plek te trek, waar hul ouers hulle nie so maklik kan bereik nie!"' (pp. 106-107.) In 1969 toon Van der Merwe (1969, p. 47) aan dat ook die gesinne op die platteland besig is om as kerngesinne te ontwikkel, en hy sê: „Dit is dus duidelik dat die ou landelike oop gesin wat geintegreer was in die familie, buurt en kerk, plek gemaak het vir 'n geslote gesinstipe wat hom, in 'n groot mate, losgemaak het van die breëre familieband, die buurt en kerk. Dit geld vir Ermelo soos reeds deur Kooy geillustreer maar ook vir die gesinne in landelike Waterberg en in die stedelike gebiede."

Hierdie struktureel geisoleerde kerngesin het enkele belangrike kenmerke, wat die gesinsdinamika op 'n besondere manier beinvloed, en die gesin in ' $n$ besondere mate kwesbaar maak.

Een van die belangrikste kenmerke van die struktureel geìsoleerde kerngesin is die feit dat die gesin ekonomies onafhanklik van die wyer verwantskapsisteem geword het, en, dat dit vir ekonomiese onderhoud in die eerste instansie van die manlike hoof van die kerngesin afhanklik is - 'n inkomste wat hy verkry deur sy werk in 'n strukturele gedifferensieerde ekonomiese struktuur buite die gesin. Die selfonderhoudende en selfversorgende aard van die uitgebreide gesin het dus hierdeur verlore gegaan. Dit word soms wel gekry dat die gesin van oriëntasie die jong epgaar aan die begin van die huwelik bystaan om in onafhanklike huishouding aan die gang te kry, maar dit is nie algemene praktyk nie en die basiese 
aanvaarde uitgangspunt is dat elke kerngesin vir sy eie lewensonderhoud moet voorsien deur die inkomste van die manlike gesinshoof.

Hierdie toedrag van sake het die gesin ekonomies besonder kwesbaar laat word. In tye van nood kan die kerngesin beswaarlik op die lede van die uitgebreide gesin of verwante vir onderhoud terugval, en verskynsels soos voortdurende werkloosheid, langdur.ge siekte en die afsterwe van die man kan dus baie maklik daartoe lei dat die gesin nooddruftig word. Ook word die ekonomiese voorsiening vir gestremdes, bejaardes en weeskinders in netelige kwessie - 'n toedrag van sake wat vir die lede van die kerngesin 'n groot mate van ekonomiese onsekuriteit kan inhou.

'n Tweede kenmerk van die struktureel geisoleerde kerngesin is die feit dat dit 'n afsonderlike woning bewoon wat nie met ander verwante of die ouers van een van die lede van die egpaar gedeel word nie. Soms woon een van die oorlewende ouers van die egpaar of ' $n$ ander familielid wel in, maar dit is meer die uitsondering as die reël.

Presies hoe wyd verspreid die alleenwonende kerngesin in Suid-Afrika voorkom, kan ongelukkig nie uit die 1960 of 1970 gegewens afgelees word nie omdat die gegewens nie in hierdie vorm verwerk is nie. Maar dat dit wel redelik verspreid voorkom, en dat verreweg die meeste kerngesinne as 'n onafhanklike eenheid sonder inwonende verwante bly, kom baie duidelik uit enkele verspreide navorsingsverslae na vore. So byvoorbeeld het $95,57 \%$ van die egpare en gesinne in Van Zyl (1948, p. 135) se steekproef alleen gewoon en het $89 \%$ van die gesinne in de Koning (1964, p. 197) se steekproef alleen gewoon terwyl net $11 \%$ verwante ingeneem het.

Afgesien van die werklike inwoning al dan nie, toon navorsing ook verder aan dat die gesinne, wat hul houdings betref, nie ten gunste van die inwoning van verwante - ook die ouers - is nie. So bv. toon de Koning $(1964$, p. 208 ) aan dat $83 \%$ mans en $78 \%$ vrouens van die gesinne beslis nie ten gunste is van die inwoning van eie of skoonfamilie nie, en Van der Merwe (1969, p. 47) toon aan dat $91 \%$ in Ermelo en $84 \%$ in Booysens/Claremont nie bereid is om hul ouers in hul huishoudings op te neem nie.

Tog moet ons hier versigtig wees met ons interpretasie van die begrip strukturele isolasie van die kerngesin van die wyer verwantskapsisteem. Dit beteken beslis nie dat die verhoudings met die gesin van oriëntasie en die wyer verwantskapsisteem verbreek word nie. Navorsing gedurende die afgelope twee dekades - ook in SuidAfrika (Van der Merwe, 1969) het baie beslis aangetoon dat daar wel bande met verwante bly voortbestaan wat baie nouer is as met ander lede van die gemeenskap, en dat daar 'n groot mate van onderlinge hulpverlening - veral finansiël, sorg in tye van siekte 
en kinderopvoeding - plaasvind. Hierdie verhoudings en wedersydse verpligtings wat onderneem word, verskil egter in aard van die uitgebreide gesinstipe deurdat in teenstelling met die uitgebreide gesin die verhoudings wat tussen wyer verwantskapsgroep en kerngesin bly voortbestaan, op 'n vrywillige basis is, meer op sentiment berus, en dat die onderlinge hulp-verlening wat oor 'n wye area kan strek, basies op eie inisiatief gedoen word met geen elemente van verpligting daaraan verbonde nie. Van der Merwe (1969, p. 20-21) toon bv. in sy navorsing aan dat feitlik alle gesinne nog kontak met hulle verwante het, maar dat hierdie kontak beslis nie die bestaan van 'n uitgebreide gesin weerspieël nie, want die grootste persentasie van die gesinne (Booysens $68 \%$, Waterberg $79 \%$, Ermelo $61 \%$ en Groenkloof $80 \%$ ) toon aan dat hulle sonder die hulp van die familie in moeilike omstandighede oor die weg sal kom, wat op 'n baie hoë selfstandigheidsgevoel by hierdie kerngesinne dui.

Hierdie strukturele isolasie van die kerngesin hou belangrike implikasies vir die gesinslewe in, want dit maak die gesin beslis meer kwesbaar en stel knelpunte daar waarvan onder ander op die volgende gelet kan word:

In die eerste instansie word gevind dat die gesin baie kleiner is, en dat waar hierdie kleiner gesin in ' $n$ eie woning dikwels geografies verwyderd van ander verwante leef, hul gedrag baie minder sigbaar vir die ander verwante is, en dat die idee dat die gesinslede toesig oor mekaar se gedrag moet hou hierdeur nie in stand gehou kan word nie, en dat dit dus nie meer moontlik is om primêre maatskaplike beheer oor hul uit te oefen nie.

Saam hiermee ontwikkel daar dan die opvatting dat die verhoudings tussen die lede van die kemgesin heeltemal privaat van aard is. Dit kom daarop neer dat die verhoudings in die gesin, synde positief of negatief, primêr die aangeleentheid van die gesinslede is en dat persone van buite - synde vriende of verwant - nie met die gesinsaangeleenthede mag inmeng nie. Kooij (1970) verwys na hierdie tipe gesin wat so sterk op sy privaatheid staan as die .geslote gesin“ en hy sê in die verband: „Wat het geindividualiseerde of gesloten gezin verlangt, is de vrijheid tot zelfontplooiing in ,zelfbestuur' ... Voor zijn ontplooiing in outonomie weet dit geïndividualiseerde gezin te behoeven een strikt ruimtelijk milieu, hoe klein dan ook, van waaruit het ongewenste penetratie vermag te weren. Dit maakt begrijpelijk, waarom het gesloten gezin, anders dan het tradisionele open gezin, geen samewoning met verwanten aanvaardt, een huisbel bezit, de toegangsdeur tot het huis heeft afgesloten en niet duldt, dat zijn kinderen door buren of zelfs nabije verwanten worden bestraft." (pp. 188-189.) 
Ook hier in Suid-Afrika dui navorsing op hierdie tendens, en wys de Koning (1964) daarop dat een van die redes wat aangevoer word vir die feit dat persone nie ten gunste is van die inwoning van verwante nie, is dat die eenheid, die intimiteit en die privaatheid van die gesin deur sodanige inwoning verlore sal gaan (p. 208).

Hierdie idee van die privaatheid, selfbestuur en selfstandigheid van die kerngesin, lei in nog 'n groter mate daartoe dat primêre maatskaplike beheer van die verwante oor die kerngesin en oor die huweliksverhouding nie geduld word nie, en daar kan dus nie op dié wyse druk op die handhawing van die huweliksverhouding uitgeoefen word nie, 'n faktor wat beslis daartoe bydra dat die kerngesin meer onstabiel word.

Afgesien van die verval van primêre maatskaplike beheer oor die kerngesin, dra 'n verdere faktor in hierdie situasie tot onstabiliteit by. Dit kom daarop neer dat as daar verhoudingsprobleme in die kerngesin kom, die gesinslede feitlik slegs op mekaar aangewese is en dat hulle nie op die ondersteuning van hul verwante kan staat maak nie om hul deur die moeilike tyd te help nie. Hulle verkies inderwaarheid om hierdie probleme, weens die siening van die private aard daarvan, nie met verwante te bespreek nie. Die kerngesin het dus hierdeur beslis in 'n struktureel onondersteunde posisie geraak en dit het daardeur besonder kwesbaar geword.

Presies hoe kwesbaar die kerngesin geword het, sal ook baie duidelik uit die volgende kenmerk, naamlik die sogenaamde emosionalisering van die kerngesin blyk.

Hierdie emosionalisering van die kerngesin kom daarop neer dat die lede van die kerngesin, in teenstelling met die lede van die uitgebreide gesin, waar ' $n$ persoon altyd deur ' $n$ groot aantal persone omring was, baie meer op mekaar vir emosionele bevrediging aangewese is en dat die verhoudings tussen die gesinslede nl. die man en vrou, die man en kinders en die vrou en kinders deur ' $n$ intense emosionaliteit gekenmerk word. Daarmee saam gaan die feit dat daar 'n polarisering in die samelewing plaasgevind het, deurdat in soverre as wat dit die gevoelslewe betref, die verhoudings binne die gesin baie intiem en sterk emosioneel gekleur is, terwyl die verhoudings na buite - in die werk en met ander lede van die gemeenskap meer onpersoonlik en sekondêr van aard is.

Hierdie emosionalisering hou beslis vir die kerngesin knelpunte in. In ' $n$ vorige afdeling is reeds aangedui dat die emosioneel gegrondveste gesinsverhouding tot die emosionele stabiliteit vir die volwasse individu bydra, deurdat die gesin in die gepolariseerde samelewing die enigste oorblywende area is waarin daar ruimte vir emosionele ontlading van die individu is.

Die spanning van die buitelewe moet dus ook deur die gesin geabsorbeer word, waardeur daar geweldige hoë eise aan die persone in hul gesinsverhoudings gestel word, en waardeur 'n 
addisionele las op hul skouers gelaai word. Cilliers (1960, p. 59) sê in die verband: "Soos reeds aangetoon, word deur hierdie omstandighede geweldige druk op die gesinslewe en veral op die huweliksverhouding, uitgeoefen. ' $n$ Hoë egskeidingsyfer is onvermydelik indien die huweliksverhouding nie hierdie geweldige las kan dra nie!"

Ook moet daarop gewys word dat waar die emosionele lewe binne die kerngesin so ' $n$ hoë mate van intensiteit het, sal die probleme wat in die gesin opduik - of dit nou as gevolg van probleme in interne verhoudings is of as gevolg van probleme wat van buite af op die gesin oorgedra word, baie meer intens ervaar word en sal teleurstellings van so ' $n$ intense aard wees dat dit die stabiliteit van die huweliksverhouding kan bedreig. Wurzbacher (1973, p. 55) sê in hierdie verband: „Sie kann sich als Tendenz zur Instabilität der Ehe äussern, da wegen der hohen Erwartungen, der Wirkungstiefe der Emotionalen Beziehungen jedes Versagen des Ehepartners ein besonders hohes Mass an Enttäuschung, Verunsicherung und sozialer Überlastung hervorruft." Daarby kom ook nou nog die feit dat die ondersteuning en maatskaplike beheer van die wyer verwantskapsisteem ontbreek, 'n toedrag van sake wat saam met die verhoogde emosionaliteit en druk daartoe lei dat die gesin besonder kwesbaar geword het.

Afgesien van die knelpunte tot dusver genoem, het hierdie kleinerwordende gesin en die daarmee gepaardgaande emosionalisering van die gesin ook belangrike implikasies vir die ouer-kind verhouding en vir die ontwikkeling van die kind in die algemeen. Aan die een kant hou hierdie klein kerngesin met die sterk intensiewe emosionele verhoudings bepaalde voordele vir die kind in. Daar kan geen twyfel wees dat die kinders in klein gesinne voordele geniet wat buite die bereik is van kinders in groot gesinne op ooreenstemmende ekonomiese en maatskaplike vlakke nie. Bossard en Boll $(1960$, p. 51) sê in hierdie verband: ,. . . they receive more in dividual attention from their parents. With fewer to consider, their value seems greater; their health and safety and security seem more important. These general considerations, when translated into specific opportunities and services, comprise many of the factors that are important in child development, and, to the contemporary parent, they outweigh other considerations..."

Tog hou hierdie klein gesin aan die anderkant ook besondere probleme vir die sosialisering van die kind in.

Een van die belangrikste probleme lê hier opgesluit in die losmaking van die geweldige sterk emosionele bande wat die kind aan sy ouers bind. Dit is reeds gestel dat die ouer-kind verhouding besonder intens emosioneel is, en dit kan waarskynlik met reg gesê word dat die ouer-kind verhouding nog nooit in die geskiedenis so intens emosioneel was as wat dit tans is nie. Tog word dit van die 
kind verwag dat om volwasse te kan word, hy hom in 'n groter mate moet losmaak en distansieer van sy eie ouerhuis as wat die geval in die uitgebreide gesin is om sodoende sy eie gesin van prokreasie te kan begin aan wie hy sy eerste lojaliteit sal moet gee en waarbinne hy sy basiese emosionele bevrediging eendag moet kry. Die groot probleem hier is dat die ouers 'n oorbeskermde houding teenoor die kind kan inneem en die kind te lank van hulle afhanklik kan hou. Bossard en Boll (1960, p. 55) sê in hierdie verband. „The emotional problem in the small family probably most emphasized in the literature is that of the child's social weaning. By 'social weaning' we mean here the readjustment of parentweaning. By 'social weaning' we mean here the readjustment of parent-child relationships in keeping with the child's growing maturity ... While it presents some difficulties for both child and parent in the large family... In the small family such transfer is more difficult or impossible, so that the process of weaning often is delayed, if not prevented entirely."

Die kind het dus 'n verder pad om te ontwikkel en te emansipeer van sy ouerhuis en hierdie emansipasie is drastieser as ooit van te vore, en indien hy dit nie regkry nie, en te 'n nou band met sy eie ouers bly behou kan dit 'n bedreiging vir sy persoonlikheidsontwikkeling asook vir sy eie gesin van prokreasie inhou - 'n faktor wat van die gesin 'n meer kwesbare instelling maak.

Die sterk emosionele band kan verder ook probleme wat betref die emosionele implikasies van dissiplinering inhou. In hierdie kerngesin word die dissiplinering in hoofsaak deur die ouers gedoen, en as die kind 'n groot mate van dissipline nodig het, of as die ouers buitengewoon dominerend is kan dit lei tot baie diepgaande emosionele konflikte in die kind. Bossard en Boll (1960, pp. 55-56) sê in die verband: "The result is a concentration of deeply conflicting emotions: of deep devotion and love by parents who do so much for their children, and of marked resentment by children against extensive disciplining. This antithesis in the child's intimate background may well be the source of many of the deepseated conflicts that characterise the current generation. It is in these respects that the small family stands in such striking contracst to the large family system."

Afgesien van hierdie emosionele probleme is daar verdere faktore in die klein kerngesin aanwesig wat die aanpassing van die kind in die buitewêreld kan bemoeilik.

So byvoorbeeld is die patroon waarop die lewe in die klein gesin georganiseer is van so ' $n$ aard dat die kind in die senter van aandag is, met veel wat vir hom gedoen word, waardeur hy 'n beeld van sy eie belangrikheid kan vorm. Hy groei dus basies op in 'n wêreld wat om homself roteer en sy selfbeeld word dienooreenkomstig gevorm. Wanneer hy tot die beroepswêreld toetree is die 
situasie gans anders - is hy slegs een tussen vele en is die kind nie goed voorbereid om ' $n$ aanpassing in die groter organisasie opset te maak nie. Bossard en Boll (1960, p. 53) sê in die verband: „What is being emphasized here is the disparity between the small-family life situation and those which most young people enter today as they leave home... There seems to be, then, this curious paradox about the small-family system, that, while it represents an adjustment to the high expectancies and ambitions of modern living, it is correspondingly inadequate training ground for performance in the realities of everyday work."

Afgesien van die ontwikkeling van 'n onrealistiese selfbeeld, is die aard van die kerngesin so, dat dit ook die kognitiewe ontwikkeling van die kind kan benadeel - 'n faktor wat verder daartoe kan bydra dat die aanpassing van die kind in die buitewêreld bemoeilik kan word. Wurzbacher (1973) vat hierdie probleem baie goed saam waar hy sê: „Nun ist aber die moderne Familie eine Kleinstgruppe, die die Komplexität der Umwelt ganz wesentlich verringert, indem sie bestimmte gesellschaftliche Probleme absorbiert, modifiziert oder ablenkt und nicht eindringen lässt. Die Kleinfamilie vereinfacht also auch die kognitiven Sachverhalte, schirmt sich von fundamentalen Konflikten der Gesellschaft ab und bewahrt sich vielmehr ein affektives, emotionales und an familistischen Kriterien ausgerichtetes Binnenklima. In diesem auf sich selbst beschränkten Familieraum scheinen kognitive Bezüge generell und damit auch die intellektuelle Entwicklung des Kindes vernachlässigt zu werden." (p. 44.)

Opsommenderwyse kan dit dus hier gestel word, dat die kerngesin weens die feit dat dit basies in 'n struktureel onondersteunde posisie is, saam met die besonder intensiewe emosionaliteit in die gesin, besonder kwesbaar geword het, beide wat betref die huweliksverhouding en die ouer-kind verhouding.

Afgesien van hierdie kwesbaarheid soos hierbo geskets, het daar nog verdere veranderinge binne die gesin plaasgevind, wat hoewel dit bepaalde voordele vir die gesinslede inhou, die gesin tog meer kwesbaar gemaak het. Een van die belangrikste veranderings in hierdie verband is dat die rolinhoude van beide die man en die vrou geweldige veranderinge ondergaan het waarop ek vervolgens wil ingaan.

Veranderinge van rolle van Man en Vrou, in implikasies ten opsigte daarvan vir die gesin

Een van die belangrikste wyses waarop die rol van die man deur die industriële revolusie geraak is, is die feit dat sy ekonomiese arbeid nie meer soos vroeër binne die huis gedoen word nie, maar in strukture buite die huis, en dat hy as gevolg daarvan lang ure van 
die huis moet weg wees. Wat die algemene invloed van die feit dat die man buitenshuis werk op die gesin betref sê Cilliers (1960, p. 47) die volgende:

„... die arbeidskring van die hedendaagse westerling vorm ' $n$ wêreld van sy eie, los van die huis en gesin. In hierdie arbeidskring word die werker as individu opgeneem, en nie in die gesinsgroep nie. Verder hang hiermee saam die feit dat die eise wat aan die individu as werker gestel word, nie alleen steeds meer en meer verskil van die eise wat die gesinslewe aan hom of haar stel nie, maar ook stceds groter en groter word. Die individu word hierdeur in 'n toenemende mate van sy gesinslede vervreem."

Een van die grootste knelpunte wat as gevolg hiervan ontwikkel, is dat die man nie altyd die tyd tot sy beskikking het om aan die kinders te bestee nie, en dat die grootste gedeelte van die kinderversorg.ng op die skouers van die vrou neerkom. Dit kan veral die sosialisering van die seun nadelig beinvloed veral as hy nie voldoende kontak met sy vader het nie, dus nie 'n model het waarop hy sy gedrag kan skoei nie en dit vir hom daardeur moeilik is om sy geslagsrol aan te leer.

' $n$ Verdere belangrike probleem in hierdie verband is dat die moeder, deurdat slegs sy voortdurend deur die dag met die kinders besig is, te ' $n$ nou binding met die kinders kan ontwikkel, dat sy deur so ' $n$ simbiotiese binding met die kinders en veral die seuns eintlik kompenseer vir die afwesigheid van die man, en dat hierdie patalogiese nou binding die selfstandigwording van die kinders geweldig kan skaad en veral vir die seun besonder nadelige gevolge bv. in terme van die ontwikkeling van homo-seksuele tendense kan hê. Dit is egter die veranderings wat die rol van die vrou sedert die industriële revolusie ondergaan het, wat die mees direkte implikasies vir die gesin in die Westerse samelewing het.

Die rol van die vrou was voor die industriële revolusie baie goed afgebaken met 'n groot mate van sekuriteit daaraan verbonde, en haar gesinsrol en werksrol het in een lewenswyse, naamlik werk by die huis versmelt. In hierdie tyd was daar ook vir haar net een rol nl. die tradisionele rol van die huisvrou en moeder oop.

Deur die Industriële Revolusie is haar werk egter uit die huis weggeneem en is sy mettertyd feitlik werkloos in haar eie huis gelaat deurdat sy vir die eerste keer haar aandeel aan die ekonomiese skema van bedrywighede in die samelewing verloor het, en ander rolle, veral die bekoringspatroon vir haar oopgegaan het. Die futiliteit van hierdie bekoringspatroon het egter by ' $n$ aantal vroue tot die eerste emansipasiebeweging gelei - 'n beweging wat mettertyd 
daartoe gelei het dat vroue in 'n toenemende mate, en veral die ongetroude vrou weer eens ten volle buite die huis indiens geneem is, sodat in die meeste lande in die westerse wêreld ongeveer $\frac{1}{3}$ van die totale arbeidsmag van dié lande uit vroue bestaan.

Ook in Suid-Afrika het die vrou deur die jare in 'n toenemende mate tot die arbeidsmark begin toetree, sodat ongeveer een derde van die totale arbeidsmark in 1970 uit vroue bestaan het en $30 \%$ van die blanke arbeidsmark uit blanke vroue bestaan het soos uit die volgende tabel blyk.

TABEL 7: PERSENTASIE VROUE VAN TOTALE EN VAN BLANKE ARBEIDSMAG - 1921-1970*

\begin{tabular}{|c|c|c|c|}
\hline & Jaar & $\begin{array}{l}\% \text { blanke vroue van } \\
\text { blanke arbeidsmark }\end{array}$ & $\begin{array}{l}\% \text { vroue van totale } \\
\text { arbeidsmark }\end{array}$ \\
\hline 1921 & …................... & $16,4 \%$ & - \\
\hline 1936 & ........................ & $17,8 \%$ & - \\
\hline 1946 & $\ldots \ldots . . . . . . \quad \ldots \ldots$ & $21,1 \%$ & $20,1 \%$ \\
\hline 1951 & ….............. & $21,8 \%$ & $19,8 \%$ \\
\hline 1960 & $\ldots \ldots . . \quad \ldots . . . . . \cdots$ & $25,7 \%$ & $23,1 \%$ \\
\hline 1970 & ........................ & $29,8 \%$ & $32,7 \%$ \\
\hline
\end{tabular}

* Uniestatistiek oor 50 jaar, Suid-Afrika 1910-1960.

Bevolkingssensus 6 Mei 1970, Verslag No. 02-01-15.

Suid-Afrikaanse Statistiek 1972.

Statistiese Jaarboek 1965.

Mettertyd het daar egter in die samelewing verdere veranderings gekom wat daartoe gelei het dat die getroude vrou in 'n tweede emansipasie beweging begin eis het om ook tot die arbeidsmark toe te tree - 'n eis wat direkte implikasies vir die gesinstruktuur inhou.

Van die belangrikste verandering in die samelewing in die verband is die volgende:

(1) Sedert die industriële revolusie was daar 'n voortdurende en drastiese afname in kindertal - iets wat nie net die werkvrag ten opsigte van kinderversorging verminder het nie, maar wat ook daartoe gelei het, dat sy gedurende 'n korter periode van haar lewensspan met die versorging van kinders besig is.

In Suid-Afrika blyk hierdie afname in kindertal duidelik uit die daling in geboortesyfer, wat soos duidelik uit die volgende tabel blyk, vanaf 32,8 per 1000 bevolking in 1904 gedaal het na 23,6 per 1000 bevolking in 1970 . 


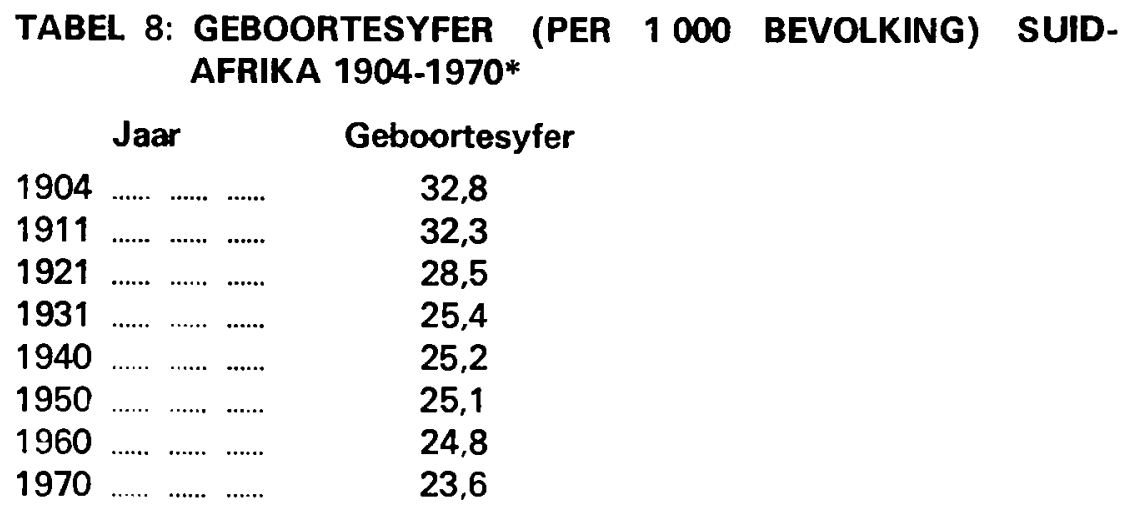

\footnotetext{
* U.G. 30/1935.

Verslag oor geboortes, Suid-Afrika S.W.A. - 1958-1963.

R/P $31 / 1965$.

Suid-Afrikaanse Statistieke, 1970.

Piek, B. J. (1965).
}

Presies wat dit in terme van werklike gesinsgrootte beteken, is dat die gemiddelde kindertal vanaf 8,9 in die tydperk $1853-1875$ gedaal het na 3,5 in 1940 soos uit die volgende tabel blyk:

TABEL 9: GEMIDDELDE KINDERTAL PER GESIN VIR SUIDAFRIKA 1853-1940*

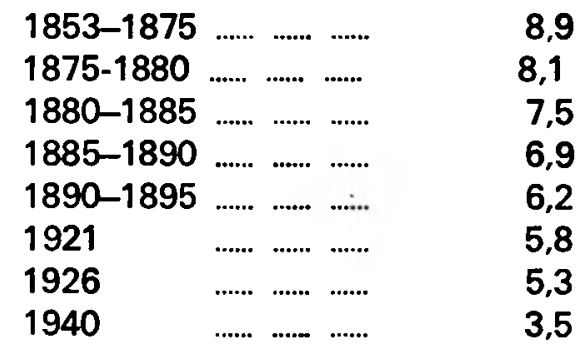

* Van der Merwe, J. D. G. (1963, p. 100).

Hoewel die gemiddelde kindertal vir 1970 nie beskikbaar is nie, is die gemiddelde gesinsgrootte wel beskikbaar, en dit is slegs 3,7, wat dui op volgehoue afname in die getal kinders per gesin. (Bevolkingsensus 1970, Verslag 02-03-01.)

(2) Saam hiermee was egter die tweede faktor wat die posisie van die vrou baie meer drasties beinvloed het, naamlik die feit dat haar lewensverwagting as gevolg van vooruitgang op mediese gebied geweldig gestyg het. 
So byvoorbeeld het in 1850 slegs die helfte van die vroulike bevolking die ouderdom van 45 bereik terwyl vandag $\pm 90 \%$ die ouderdom van 65 bereik, met die algemene lewensverwagting hier in Suid-Afrika 71 jaar vir blanke vroue.

Hierdie faktore het daartoe gelei dat die vrou dikwels op 'n vroeë leeftyd voor die sogenaamde leë nes te staan kom waar haar kinders groot en uit die huis is en dat sy met ' $n$ hele aantal jare voor haar sit waar sy nog lewenskragtig genoeg is om ' $n$ bydrae tot die samelewing te maak. Dit is dus te verstane dat daar in ' $n$ toenemende mate ' $n$ behoefte by ' $n$ groter wordende persentasie van die getroude vrouens ontstaan om op die lang duur iets meer met hul lewens te doen as slegs huisvrou en moeder te wees. Veral in die groot stad van vandag waar die vrou dikwels nie haar bure ken nie, haar man heeldag by die werk is en haar kinders uit die huis is, kan sy maklik 'n gevoel van vereensaming, doelloosheid, en frustrasie ontwikkel, wat die huweliksverhouding nadelig kan raak.

Die reaksie van die vrou op hierdie situasie is uiteenlopend van aard. Sommige reageer daarop deur ' $n$ ooraktiewe deelname aan die sosiale lewe. Ander los die probleem op deur 'n deelname aan verenigingslewe - wat basies 'n sosiaal gesonde reaksie is. 'n Derde groep vroue hanteer die probleem deurdat sy weer eens tot die arbeidsmark wil toetree. Hoewel sommige getroude vroue weens ekonomiese noodsaak tot die arbeidsmark toetree, is daar in 'n toenemende mate getroude vroue wat beroepe begin beoefen en omdat dit sinvolle inhoud aan hul lewens gee en hulle 'n groot mate van bevrediging daaruit kry.

Hierdie toetrede van die getroude vrou tot die arbeidsmark kry weliswaar nog teenstand van samelewingskant - veral as die vrou se kinders nog klein is. Tog word hedendaags vry algemeen aanvaar dat veral die getroude vrou wat nog nie kinders het nie, en dié wie se kinders reeds uit die huis is, wel tot die arbeidswêreld $k a n$ toetree. Die feit dat hierdie getroude vroue in ' $n$ toenemende mate tot die arbeidsmark toetree blyk baie duidelik uit die sg. kameelrugkurwe, wat verkry word as die deelname van die vrou aan die arbeidsmark volgens haar ouderdom ontleed word. Hieruit blyk duidelik dat daar ' $n$ afname aan haar deelname aan buitenshuise arbeid is na die 25 ste jaar - die tyd wanneer sy normaalweg klein kinders by die huis het, en dat daar weer ' $n$ toename aan haar deelname is vanaf ongeveer die 35 ste jaar - die tyd wanneer haar kinders groter begin word en uit die huis begin gaan (Sullerot, 1969 . p. 118).

Ook in Suid-Afrika begin die getroude vrou in 'n toenemende mate tot die arbeidsmark toetree. 
TABEL 10: BLANKE VROUENS IN ARBEIDSMAG VOLGENS HUWELIKSTAAT 1946-1951

\begin{tabular}{|c|c|c|c|}
\hline Huwelikstaat & I946* & 1951 ** & $1960 * *$ \\
\hline Ongetroud $\quad \ldots . . . . . . . . . . . . .$. & 67,9 & $55 \%$ & 41,3 \\
\hline Getroud $\ldots \ldots \ldots \ldots \ldots \ldots$ & 19,7 & $31,1 \%$ & 44,8 \\
\hline 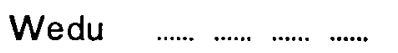 & 8,1 & $7,9 \%$ & 8,3 \\
\hline Geskei $\quad \ldots \ldots \ldots \ldots \ldots$ & 4,3 & $4,9 \%$ & 5,3 \\
\hline
\end{tabular}

* Prinsloo (1957, p. 365)

* Wessels (1961, p. 51).

** Georg \& Mayer (1970, p. 37).

Soos uit die tabel gesien kan word was daar van 1946 tot 1960 ' $n$ drastiese toename in die persentasie getroude vroue wat tot die arbeidsmark toegetree het, $\mathrm{nl}$. vanaf $19,7 \%$ tot $44,8 \%$.

Ongelukkig is dit nie moontlik om te bepaal of die deelname van vroue volgens ouderdom hier te lande 'n kameelrugkurwe toon nie, omdat offisiële statistiek in die verband ontbreek. Ook is dit nie moontlik om dit uit individuele stukke navorsing af te lei nie omdat die navorsers nie die grootte van hul kategorieë vir hul ontledings konstant gehou het nie (Sien J. van der Merwe, 1963, D. Wessels, 1961 en George \& Mauer, 1970).

Wanneer hierdie syfers, ook hier in Suid-Afrika, nagegaan word, kan daar dus met reg beweer word dat naas die vrou-en-moeder rol en die bekoringspatroon nog ' $n$ derde rol vir die vrou ontstaan het, naamlik die kameraadskaps- of venootskapsrol waar sy saam met die man vir die finansies van die gesin verantwoordelik is en die verhouding tussen haar en haar man meer een van gelykheid is.

Hierdie verskeidenheid van rolle wat vir die vrou oopstaan, skep heelwat probleme vir haar, en as hulle nie reg hanteer word nie, kan hulle probleme in die gesinslewe oplewer.

Omdat daar drie rolle is waaruit die vrou 'n keuse kan doen is daar by haar ' $n$ mate van onsekerheid oor haar rol, en kan daar vir haar in die uitlewing van haar rol konflikte ontstaan wat 'n gesonde gesinslewe kan benadeel. Ook kan die feit dat sy en haar man verskillende opvattings het omtrent die aard van die rol wat sy behoort te vervul, tot huweliksonenigheid lei en so ' $n$ knelpunt in die gesinslewe vorm.

In ' $n$ vorige paragraaf is reeds aangetoon dat die vrou wat slegs huisvrou is voor probleme te staan kom wat vir die gesinsharmonie skadelik kan wees. Navorsing toon dan ook aan dat die rol wat aan die bekwame, inteliggente en emosioneel volwasse vrou die grootste moontlike bevrediging gee, die sg. vennootskaprol is, waar sy ook 'n beroep beoefen. Hierdie rol hou egter ook nog baie probleme in wat die gesinslewe nadelig kan beinvloed. 
Een so 'n probleem is dat dit soms noodsaaklik is dat die man ook ' $n$ deel van die verantwoordelikhede van die huis op hom moet neem om haar so in staat te stel om voltyds ' $n$ beroep te kan beoefen. Hierdie rolverandering by die man word nog nie hier in Suid-Afrika met al sy implikasies deur hom aanvaar nie, hoewel navorsingsresultate aandui dat daar tekens van 'n groter aanvaarding veral in die stad is.

So toon Van der Merwe (1969, p. 37) aan dat hoewel in Ermelo $45 \%$ en in Waterberg $50 \%$ van die mans hul vrouens nooit met huishoudelike take help nie in Groenkloof slegs $19 \%$ en in Booysens slegs $28 \%$ van die mans dit nooit doen nie. Hierdie probleem kan egter konflik in die gesin veroorsaak en Prinsloo (1972, p. 198) vind dan ook dat daar by getroude vroue wat werk groter rolkonflik is as by nie-werkende getroude vroue. Hierdie toedrag van sake kan dus 'n knelpunt in die gesinslewe vorm.

'n Ander probleem in hierdie verband is dat hoewel die man die vrou wel in die huis behulpsaam mag wees, die finale verantwoordelikheid van die huishouding tog nog op haar skouers rus en dat sy dus saam met haar werk 'n dubelle verantwoordelikheid dra, wat haar moeg en prikkelbaar kan maak en so haar gesinsverhoudings kan benadeel.

'n Derde probleem waarvoor die werkende getroude vrou te staan kom, is dat as haar kinders nog op ' $n$ voorskoolse stadium is, hulle soveel tyd en aandag eis dat sy letterlik nie haar beroep voltyds kan beoefen nie en dat sy haar volle aandag aan haar kinders moet gee - die moeder-kind-verhouding gedurende die baba- en kleuterstadium is van soveel belang vir die ontwikkeling van die kind dat die moeder gedurende hierdie tyd liefs nie voltyds 'n beroep moet beoefen nie. Selfs as haar kinders op skool is, is dit verkieslik dat sy in die middae saam met hulle tuis moet wees.

Daardeur word aan hulle die grootste mate van sekuriteit gegee. Deeltydse werk kan hier 'n belangrike oplossing wees om die posisie van die vrou te vergemaklik en sodoende die druk op die huisgesin te verminder. Ongelukkig is daar nie voldoende deeltydse werk beskikbaar nie, en Wessels (1971, p. 53) toon in hierdie verband aan dat aanbod van goed opgeleide vroue vir deeltydse werk die vraag na hulle arbeid aanmerklik oorskry.

'n Besonder belangrike knelpunt hier is die sorg waarin die voorskoolse kind en ook die skoolgaande kind in die afwesigheid van die moeder geplaas word - 'n faktor wat beslis die ontwikkeling van die kind kan beinvloed. Indien die kleuter in gespesialiseerde sorg van 'n kleuterskool geplaas word, kan dit vir hom voordelig wees, omdat sy milieu daardeur geweldig verryk word, en dit kan ook deels die knelpunt ten opsigte van die kognitiewe ontwikkeling van die kind in die klein kerngesin, en sy latere aanpassing in die buitelewe deels verlig. Word die kind egter in die sorg van in 
bediende gelaat kan dit vir hom nadelig wees, omdat die bediende dikwels nie die skoling en die vlak van ontwikkeling van die ouers het en sy nie die intellektuele ryk omgewing kan skep wat die eie moeder kan gee nie, en die kind dus op die wyse milieu-gestremd kan raak. Wurzbacher (1973, p. 37) toon bv. aan dat die kind van die laer geskoolde arbeider se ontwikkeling beslis weens die laer nivaeu wat in die huis gehandhaaf word, skade ly teenoor die kind wat groot word in 'n huis waar die ouers hoër ontwikkeld is. Hierdie situasie geld dus ook waar 'n bediende met laer skoling die kinders vir die grootste gedeelte van die dag versorg.

Presies wat die omvang van ouers wat hul kinders in die sorg van bediendes laat, is, is moeilik om te bepaal. Individuele stukke navorsing toon aan dat dit 'n aansienlike persentasie kan wees. So bv. vind Van der Merwe (1973, p. 199) dat in $47,1 \%$ van die gesinne in sy steekproef (grootte 1450 ) die kinders deur bediendes versorg word, en dat $9,2 \%$ van die gevalle niemand tuis is om toesig oor die kinders te hou nie. Wessels (1960, p. 122) toon aan dat byna 'n $\frac{1}{3}$ van die gesinne in haar steekproef (951 gesinne) voorskoolse kinders gehad het en dat $32,54 \%$ van hierdie kinders by nie-blanke bediendes gelaat is. Sy toon ook aan dat slegs $3,9 \%$ van die gesinne van instansies soos bewaar- en kleuterskole gebruik gemaak het, en wys daarop dat hierdie geringe gebruikmaking nie noodwendig beteken dat moeders ongeneë is om hulle te gebruik nie, maar toon eerder aan dat daar nog 'n groot tekort aan sodanige fasiliteite is. 'n Belangrike vraag wat dus hier gestel kan word, is of daar nie meer aandag aan die oprigting van kinderbewaar- en kleuterskole gegee moet word nie? Word Kleuterskole nie op te 'n lukraak basis opgerig nie? Is dit nie tyd dat instansies wat 'n groot persentasie getroude vroue indiens neem verpligtend bewaarskole moet oprig nie? Die daarstelling van sulke hulpstrukture in die samelewing kan 'n groot deel van die stremming in die gesinslewe verwyder en ook bydra tot die versekering dat die persoonlikheidsontwikkeling van die kind nie skade ly nie.

Samevattend kan dus wat die rollestruktuur in die gesin betref aangedui word dat dit nog tot heelwat knelpunte in die gesin lei, en dat daar grondig gesoek sal moet word na nuwe strukture wat 'n bydrae sal kan maak tot die verligting van hierdie knelpunte in die gesin.

\section{Geatomiseerde Stedelike lewe}

'n Laaste knelpunt waarna ek hier vlugtig wil verwys, en wat verband hou met die komplekse stedelike lewe in die algemeen, is nl. die gebrek aan gesinseenheid wat kan voortvloei uit die geinndividualiseerde lewenspatrone wat feitlik deur die geïndustrialiseerde samelewing op die mens afgedwing word. 
As gevolg van hierdie lewenspatroon is dit vir die individuele gesinslede so maklik moontlik om elk sy eie belangstellings te ontwikkel en elk sy eie koers te gaan, dat daar soms nie in die gesin tyd is om as gesin saam te verkeer nie en daardie atmosfeer van warmte toegeneentheid en sekuriteit te kweek wat so noodsaaklik vir die gesonde groei van die kinders is nie. Sonder dat daar dus noodwendig swak verhoudings of uitermate botsings in die gesin voorkom, is daar egter ook 'n gebrek aan eenheid en leef die individue net bymekaar verby.

Die man leef hom in sy werk uit, die kinders is voortdurend besig met skoolwerk of naskoolse bedrywighede, en die vrou se aktiwiteite voer haar ook dikwels uit die huis weg, synde dit sosiale- of verenigings- of arbeidsbedrywighede.

Dikwels is hierdie gebrek aan eenheid nie so opvallend as die kinders in die huis is nie, maar as die ouers by die sg. leë nes stadium gekom het, waar al die kinders uit die huis is, dan vind die ouers dat hulle niks meer in gemeen het nie en dat elk sterk ontwikkelde eie belang het. Die is dus nie vreemd as die egpaar bloot besluit om „uitmekaar" te gaan nie. Dit is dan ook besonder interessant om daarop te let dat daar 'n toename in egskeidings is by egpare wat 20 jaar en meer getroud is. So toon offisiële statistiek*

* Sien Statistiese Jaarboek 1964, en

Statistieke van egskeidings van Suid-Afrika, Verslae No. 07-04-05 en 07-04-05.

aan dat van al die egskeidings in $194511,5 \%$ van die pare 20 jaar en meer getroud was, terwyl dit in 1967 met $15,0 \%$ en in 1971 met $14,5 \%$ die geval was.

\section{SLOT}

En nou, wanneer ek 'n terugblik werp op die knelpunte in die gesin soos hier geskets, en op die aspekte ten opsigte waarvan die gesin in ons ingewikkelde samelewing kwesbaar geword het, en ek dink aan die probleme waarvoor die jonggetroude en ook die ouer getroude paar in die huweliks- en gesinslewe te staan gaan kom, dan kom daar een baie belangrike vraag by my op, en dit is naamlik - is ons jongmense voldoende op die huweliks- en gesinslewe voorbereid? Is een van die grootste knelpunte nie die feit dat hulle onvoorbereid met hul grootste lewenstaak gaan begin nie? Is dit nie tyd dat ons op nasionale skaal aandag aan huweliks en gesinsvoorligting - en nou bedoel ek beslis nie net seksvoorligting nie moet begin gee nie?

Ten slotte wil ek net graag samevattend daarop wys dat dit baie duidelik is dat daar besonder baie knelpunte in die gesinslewe is - knelpunte wat individuele gesinne kwesbaar maak en op die rotse laat loop. Dit is dus dringend noodsaaklik dat 'n grondige navorsingprogram begin moet word-navorsing wat baie geld sal kos, en waarvoor ek bevrees is met die huidige toebedeling van 
fondse aan geesteswetenskappe daar beslis nie voldoende fondse sal wees nie - om vas te stel hoe hierdie probleme die beste die hoof gebied kan word. En in hierdie taak van ons moet ons meer toekoms gerig wees, en moet ons gaan soek na wyses waarop die knelpunte verminder kan word, of na nuwe hulp strukture waardeur die knelpunte uit die gesin verwyder kan word om sodoende die gesin ' $n$ meer stabiele eenheid met 'n hoë mate van sekuriteit te maak.

\section{BRONNELYS}

Bezuidenhout, G. P. H.: Die Maatskaphke Implikasies van Skofwerk vir die Gesinslewe aan die hand van toestande in 'n Nywerheidsvoorstad in Pretoria, M.A., U.P., 1972.

Blignaut, J. H.: Geweśe inwoners van die Abraham Kriel-Kinderhuis - 'n Sosiologiese ondersoek met besondere verwysing na die huweliks- en gesinslewe, D.Phil., U.P., 1965.

Bodenstab, A. T. B. H. \& V̈enter, J. P. A.: „Is die daarstelling van ,Kinder parkades', 'n gewenste praktyk of nie", Volksgesondheid, Vol. 72, Des. 1972, pp. 389-397.

Bossard, J. H. S. \& Boll, E. S.: The Sociology of Child Development, Harper \& Brothers, New York, 1960.

Botha, J. N.: Die intrek van landelike gesinne in die stad met besondere verwysing na die arbeid, veral nz aanleiding van in sosiologiese ondersoek wat aan die Witwatersrand en in Pretoria ingestel is. M.A., U.P., 1942.

Cilliers, S. P.: Gesonde Gesinsbou, Universiteitsuitgewers en Boekhandelaars, Stellenbosch, 1960.

Coetzee, J. H.: Huweliks- en Gesinsverandering in Suid-Afrika, M.A., Johannesburg, 1939.

Cronje, G. (Red.): Ouer en Kind: Gesinshandboek, N.G. Kerk Uitgewers.

Cronje, G.: "Afrikaanse familievorm", Hertzog-Annale van die Suid-Afrikaanse Akademie van Wetenskap en Kuns, Vol. 10, 1963, pp. 95-107).

Cronje, G.: „Aandeel van die Blanke vrou aan die beroepsarbeid in Suid-Afrika met besondere aandag aan die gesinsimplikasies van die beroepswerksaamheid van die getroude vrou". Tydskrif Geesteswetenskappe, Vol. 5 . Junie 1965, pp. 220-232.

Cronje, G.: Krimpends Kindertal: Waarom Huisgesinne Kleiner word, N.G. Kerk Uitgewers, Kaapstad, 1958.

Cronje, G.: Kinders Sonder Sorg: Hoe ouers hul k.nders verwaarloos, N.G. Kerk Uitgewers, 1959.

Cronje, G.: Egskeiding en Huweliks- en Gesinsontbinding, N. Y. Swets \& Zeitlinger, Amsterdam, 1933.

Cronje, G.: Mian en Vrou in die Huwelik, H.A.U.M., Kaapstad-Pretoria, 1959.

Cronje, G.: Egskeiding: Die aard en oorsake van huweliksontbinding in SuidAfrika, N.G. Kerk Uitgewers, 1959.

Cronje, G. \& Venter, J. D.: Die Patriargale Familie, Kaapstad, H.A.U.M., 1958.

De Koning. T. L.: Die Gesinstruktuur en -funksionering van ' $n$ aantal Kleinhoewe gesinne om Pretoria, M.A., Unisa, Nov. 1964.

Du Toit, J. B., Steyn, A. F., \& Rip, C.: Afwykende Gedrag: 'n Studie van Enkele Maatskaplike probleme, Nasou Bpk., 1970.

Eisenstein, V. W. (M.D.): Neurotic Interaction In Marriage, Basic Books, N.Y., 1956.

Engelbrecht, J.: Die Fertiliteit van 'n groep Blanke Afrikaanssprekende Vroue in Pretoria, Nas. Buro vir Opv. en Maatskaplike Navorsing. Pretoria, 1968.

Fouche, J. W. J.: Die persoonlike en gesinsagtergrond van 1975 onbeheerbare kinders wat gedurende $1956 / 57$ na inrigtings verwys is, M.A., U.P. 1957.

Fourie, C.: „Ondersoek van die invloed van die werksomstandighede op die persoonlike en gesinslewe van 'n groep getroude blanke fabrieks-werksters in 'n stedelike gebied van die R.S.A.", Tydskrif vir Mastskaplike Navorsing. Vol. 13, 1962, pp. 95-99.

Fourie, Cora: 'n Ondersoek van die invioed van die werksomstandighede op die persoondike- en gesinslewe van 'n groep getroude blanke vroulike fabriekswerksters in 'n stedelike gebied van die Unie van Suid-Afrika, met die oog op bepaling van 'n welsynsbeleid, M.A., U.O.V.S.

George, I. \& Mauer, E.: Blanke Vroue-arbeid in Suid-Afrika: in Bronnestudie, W.N.N.R. Verslag No. Pers. 130, Maart 1970. 
Gesinswelsyn in Suid-Afrika, Verslag van die verrigtinge van die Suid-Afrikaanse Nasionale Gesinswelsynskongres, Johannesburg, 17-22 Mei 1954.

Goode, W. J.: World Revolution and Family Pattems, Free Press of Glencoe, III., 1963.

Goode, W. J.: The Family, Prentice-Hall, 1964.

Gouws, D. J.: „Psychological aspects of female employment (more particularly in the higher occupational categories)" Manufacturer, Vol. 14, No. 7, Julie 1964, pp. 16-19.

Higgings, E.: .,Bearing of family allowances on family size in an urban white population", J. Social Res., Vol. 12, May 1962, pp. 165-176.

Hoernlé, A. W.: "Some comments on the status of the family in South Africa" Blourestocking, Vol. 10, Feb. 1940, pp. 1-12.

Jammine, E. J.: A Sociologicał study of assisted Housing schemes provided for low-income Group Families in Pretoria with particular reference to home-ownership, M.A., U.P., 1960.

Keyter, J. de W.: Die Huwelik en Gesin, Nasionale Pers, 1940.

Kleynhans, E. P. J.: Die Huweliksvrugbaarheid van die Blanke Suid-Afrikaner: in Prinsipiële histories-sosiologiese studie, M.A.

Kooy, G. A.: Het Modem Westers Gezin, Paul Brand, Hilverson, 1970.

La Grange, F. H.: Aanpassing van die vrou in die Egskeidingsituasie, D.Phil. U.S., 1970.

Linner, B. \& Litell, R. J.: Sex and Society in Sweden, Jonathan Cape, London, 1968.

Lombard, J. C.: Die huwelik en gesin Sosiologies gesien: In die lig van die Wysbegeerte van die Wetsidee, M.A., Potchefstroom.

Machanik, G.: „Hey, you idle White women! Statistical analysis of the economically inactive", Commercial Op:nion, Vol. 47, No. 564, Jan. 1970, pp. 8-9.

McLachlan, R.: Sorgebehoewende Kinders: 'n Sosiologiese studie van Hulle Gesinsagtergrond, U.P., D. Phil., 1958.

McLennan, I. M.: "Boksburg-Benoni-hospitaal: ons hospitaalcrèche" South African Nursing Journal, Vol. 38, No. 10, Okt. 1971, pp. 9-12.

Mostert, W. P.: 'n Ondersoek na die Gesinsbouproses by Afrikaanssprekende egpare Fase 1: Fertiliteitsbegeertes en Gesinsbeplanning by pasgetroudes, R.G.N., Pretoria, 1970.

Navorsing \& Inligting: Dept. van Volkswelsyn en Pensioene, Evaluase van die Gesinstoelaeskema, Uitgawe No. 2, 1967.

Navorsing \& Inligting: Dept. van Volkswelsyn en Pensioene, Maatreëls ter bevordering van die Gesinsiewe in Suid-Afrika, Uitgawe No. 2, 1971.

Neidhart, F.: Struktur und Wandel der Gesellschaft: Die Familie in Deutsland, C. W. Lerke, Oplag Verladen, 1966.

Parsons, T.: Essays in Sociological Theory, Free Press, Glencoe, III., 1954.

Parsons, T., \& Bales, R. F.: Family, socialization and Interaction Process, Free Press, Glencoe, III., 1955

Pauw, S. \& Van Rooyen, I. J. J.: "Gesin as instelling en volkskern”, Lantern, Vol. 9, No. 4, April-Julie 1960, pp. 29-31.

Piek, H. J. (Voorsitter): Verslag van die komitee van ondersoek in sake gesinstoelae, Des. 1961.

Piek, B. J.: 'n Sosiologies-Demografiese studie van tendense in die leeftydsamestelling van ' $n$ bevolking, met besondere verwysing na blankes in Suid-Afrika, D.Phil., U.P., 1965.

Prinsloo, E. C.: Die verband tussen beroepsbeoefening deur die moeder, rolkonflik in die huwelik en huweliksukses by die stedelike middelklasbevolking van Suid-Afrika, M.A., Unisa, 1972.

Prinsloo, M. J. M.: Blanke vroue-arbeid in die Unie van Suid-Afrika, Van Gorcum \& Co., 1957.

Prinsloo, M. J. M.: „Beroepsarbeid van die vrou en moeder", Lantern, Vol. 9, No. 4, April-Julie 1960, pp. $88-89+$.

Report on the Family Congress, Pretoria 4-7 April 1961.

Retief, G. M.: 'n Ondersoek na die wyse waarop die gesinsagtergrond van jeugoortreders van veroorsakende betekenis in die bepaling van hul wangedrag is, M.A., U.P., 1951.

Roode, C. D.: 'n Sosiologiese Ondersoek van die Huislike agtergrond van Onbeheersbare Jeugdiges, gebaseer op die Amptelike Rekords in die Dept. van Volkswelsyn, Pretoria, M.A., U.O.V.S., 1961.

Scholten, W. H. J.: ..Ekonomiese struikelblokke in die weg van ouerskap", Tydskrif Rasse-aangeleenthede, Vol. 20, Jan. 1969, pp. 39-48.

Seawright, T. R.: A Social Casework Approach to Marriage Counseling, Witwatersrand Univ. Press, 1961.

Strating. H.: „Problematiek van die vrou in die huidige gesinslewe", Tydskrif vir Geesteswetenskappe, Vol. 5, Jun. 1965, pp. 159-174. 
Sullerot, E.: De Vrouenarbeid in onze tijd, Paul Brand, Bussum, 1969.

Unterhalter, B.: „Characteristics and reactions of families to life in a density residential area of Johannesburg, South Africa", Humanitas, Vol. 1, 1972, pp. 211-217.

Van der Merwe, A.: Die Huwelik: 'n Histories-Sosiologiese Studie van die huwelik as instelling. met besondere verwysing na Suid-Afr.kaanse Ontwikkelings, D.Phil., Bloemfontein, 1952.

Van der Merwe, C. F.: Die Afrikaanse Landelike en Stedelike gesin: 'n Vergelykende ondersoek, R.G.N., Instituut vir Sosiologies Navorsing, 1969.

Van der Merwe, C. F.: Die Beroepswerksame getroude Vrou met Gesinsverantwoordelikheid. 'n Sosiologiese Ondersoek in Pretoria, D.Phil., U.P., 1973.

Van der Merwe, J.: 'n Sosiologiese ondersoek na die Gesinslewe van die stad Germiston, D.Phit., U.P., 1963.

Van der Merwe, J. D. G.: "Onverenigbaarheid in die huwelik en die gesin", Lantem, Vol. 9, No. 4, April-Julie 1960, pp. 68-69+.

Van Wyk, Cecilia Johanna: Enkele aspekte van Blanke Vroue-arbeid in Johannesburg: 'n Sosiologies ondersoek, M.A., U.P., 1968.

Van Zijl, D.: Die Gesinsiklus in Suid-Wes Kaapland, D.Phil., U.S., 1948.

Van Rooyen, I. J. J.: 'n Ontleding van die Gesinsagtergrond van Blanke Sorgbehoewende Kinders in Suid-Afrika en van die Rehabilitasie metodes wat in die verband aangewend word, D.Phil., Unisa, 1956.

Venter, J. D.: Die Kenmerke van die patriargale Familie, M.A., U.P., 1957.

Wessels, D. M.: Vroue en Moeders wat werk: Die invloed van hul beroepsarbeid op die huisgesin en die volk, N.G. Kerk Uitgewers, Kaapstad, 1960.

Wessels, D. M.: Die Vrou in die Beroepslewe: Die aard en Omvang van Vrouearbeid in Suid-Afrika, Kaapstad, H.A.U.M., 1961.

Wessels, D. M.: Deeltydse werk vir getroude vroue: Vraag-en aanbodsituasie in Pretoria, R.G.N., 1971.

Wessels, D. M.: Die Arbeidspatroon van gegradueerde huisvroue in die P.W.V.-gebied, Deel I, Deeltydse Werk, R.G.N., Pretoria, 1972.

White, I. H. B.: .Effect of industry on family life", Manufaturer, Vol. 7, No. 4, Féb. 1957, pp. 27-29.

Wurzbacher, G. \& Cyprian, G.: Probleme der Familie und der Familien politik in der B.R.D., Görres Druckerei, Koblenz, 1973.

U.G. 30/1935:

\section{OFFISIELE STATISTIEK}

Verslag oor die Lewensstatistiek Unie van Suid-Afrika, 1933

Bevolkingsensus 6 Sept. 1960: Boekdeel 7, No. 2: Eienskappe van bevolking in elke landdrosdistrik en Ekonomiese Streek, Beroep ,Nywerheid en tipe woning.

Bevolkingsensus $6 \mathrm{Mei}$ 1970: Steekproeftabellasie - Ouderdomme-Blankes; Verslag No. 02-01-01.

Bevolkingsensus 6 Mei 1970: Steekproeftabellasie, Beroepe - Blankes, Kleurlinge \& Asiërs, Verslag No. 02-01-05.

Uniestatistieke oor Vyftig Jaar - 1910-1960 - Unie van Suid-Afrika - Buro vir Sensus en Statistiek.

Statistiese Jaarboek 1965.

Suid-Afrikaanse Statistieke 1966.

Suid-Afrikaanse Statistieke 1967.

Suid-Afrikaanse Statistieke 1968.

Suid-Afrikaanse Statistieke 1969.

Suid-Afrikaanse Statistieke 1970.

Suid-Afrikaanse Statistieke 1971.

Suid-Afrikaanse Statistieke 1972.

Verslag oor Geboortes, Suid-Afrika en Suidwes-Afrika, 1958-1963 R/D 31/1965.

Special Report No. 214, Dissolution of Marriage, 1956 \& earlier years. Verslag oor huwelike 07-02-13.

Statistieke van egskeidings in Suid-Afrika.

1971. Verslag No. 07-04-05.

1967, 1968, 1969, 1970, Verslag No. 07-04-04.

1966, Verslag No. 07-14-13.

Report on Marriage, U.G. 38/58, 1957 and earlier years.

Verslae oor huwelike, Suid-Afrika.

1965 Verslag No. 07-12-02.

1966 Verslag No. 07-02-03.

1967-1970 Verslag No. 07-02-04.

1971 Verslag No. 07-02-05.

Bevolkingsensus 1970: Gesinne: Geografiese Verspreiding, Verslag No. 02-03-01. 